\title{
Bone Healing Evaluation Following Different Osteotomic Techniques in Animal Models: A Suitable Method for Clinical Insights
}

\author{
Alexandre Anesi ${ }^{1, *(\mathbb{D}}$, Mattia Di Bartolomeo ${ }^{2}$, Arrigo Pellacani ${ }^{2}$, Marzia Ferretti ${ }^{3}$,

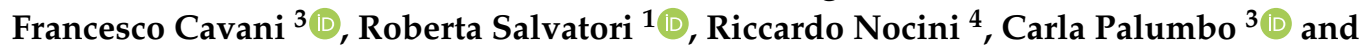 \\ Luigi Chiarini ${ }^{1}$ \\ 1 Department of Medical and Surgical Sciences for Children \& Adults, Cranio-Maxillo-Facial Surgery, \\ University of Modena and Reggio Emilia, Largo del Pozzo 71, 41124 Modena, Italy; \\ roberta.salvatori@unimore.it (R.S.); luigi.chiarini@unimore.it (L.C.) \\ 2 Unit of Dentistry and Maxillo-Facial Surgery, Surgery, Dentistry, Maternity and Infant Department, \\ University of Verona, P.le L.A. Scuro 10, 37134 Verona, Italy; mattiadiba@hotmail.it (M.D.B.); \\ arrigo.pellacani@libero.it (A.P.) \\ 3 Section of Human Morphology, Department of Biomedical, Metabolic and Neural Sciences, \\ University of Modena and Reggio Emilia, Largo del Pozzo 71, 41125 Modena, Italy; \\ marzia.ferretti@unimore.it (M.F.); francesco.cavani@unimore.it (F.C.); carla.palumbo@unimore.it (C.P.) \\ 4 Section of Ear Nose and Throat (ENT), Department of Surgical Sciences, Dentistry, \\ Gynecology and Pediatrics, University of Verona, 37124 Verona, Italy; riccardo.nocini@gmail.com \\ * Correspondence: alexandre.anesi@unimore.it; Tel.: +39-059-422-4552
}

Received: 15 September 2020; Accepted: 11 October 2020; Published: 14 October 2020

\begin{abstract}
Osteotomy is a common step in oncological, reconstructive, and trauma surgery. Drilling and elevated temperature during osteotomy produce thermal osteonecrosis. Heat and associated mechanical damage during osteotomy can impair bone healing, with consequent failure of fracture fixation or dental implants. Several ex vivo studies on animal bone were recently focused on heating production during osteotomy with conventional drill and piezoelectric devices, particularly in endosseous dental implant sites. The current literature on bone drilling and osteotomic surface analysis is here reviewed and the dynamics of bone healing after osteotomy with traditional and piezoelectric devices are discussed. Moreover, the methodologies involved in the experimental osteotomy and clinical studies are compared, focusing on ex vivo and in vivo findings.
\end{abstract}

Keywords: bone healing; bone damage; bone injury; bone surgery; osteotomy; drilling; piezosurgery; in vivo; ex vivo

\section{Historical Background}

Osteotomy consists of cutting the bone. In clinical practice, it is a surgical procedure in which a bone is divided or a piece of bone is excised.

Specifically, bone cutting techniques can be classified into two types: osteotomy that requires a full-thickness division of the bone and corticotomy in which only the bone cortex is divided with preservation of the periosteal and endosteal layers [1].

Osteotomy is an ancient surgical skill dating back to Hippocrates circa 415 BC, who used a new fracture to improve the alignment of a previously angulated humerus because of trauma [2].

Corticotomy was first described by Ilizarov in the 1950s as a low-energy division of the bone cortex preserving both the periosteum and the medullary vascularization in order to increase bone neoformation and elongation [3] (hereinafter referred to as distraction osteogenesis). Since then, several 
osteotomy procedures have been developed for deformity correction or bone lengthening-in particular, by De Bastiani et al. during the 1980s [2].

In 1991, Paly and Tetsworth introduced the percutaneous Gigli saw technique, also known as the Afghan technique, as a new procedure for performing minimally invasive low-energy osteotomies in long bones that leaves a very smooth cut, especially important for rotational correction $[2,4,5]$. Shortened duration of surgery, minimal soft-tissue damage and periosteum preservation make this technique one of the most recommended still today $[4,6,7]$. According to our experience, however, a low level of consistency between planning and execution characterizes the geometry of the osteotomy plane by Gigli saw, because of the intrinsic poor control of the device with complex angulations.

Later, motorized rotatory and oscillating cutting tools were developed, which have greatly simplified the surgical performance, allowing a precise and direct cut. Nevertheless, power saw osteotomies have several disadvantages, such as the requirement for a relatively large open exposure, the risk of tissue overheating resulting in possible thermal necrosis and soft tissue trauma.

In order to reduce these complications, ultrasound-based osteotomy techniques (Piezosurgery ${ }^{\circledR}$ ) have been developed in recent years [8]. In particular, its development was encouraged by the need for high levels of precision and safety in bone surgery compared with that achieved by standard bur and saw instruments [9].

Parallel to the latter method, interest in the possibility of applying lasers to surgical osteotomies has also grown in recent years. In general, several studies have shown that the advantages of laser osteotomy are numerous, such as sterilization of the operative field (bactericidal effect) and simultaneous hemostasis during the cut, resulting in less bleeding and risk of infections, less post-operative pain and edema, faster recovery, need for smaller surgical access and limited scarring [10]. The Er:YAG laser, in particular, would seem to minimize the thermal damage of the bone and surrounding tissues $(5 \mu \mathrm{m})$ [11] and promote faster healing due to the osteoinductive effect, as well as allowing a very precise cut and minimal invasiveness [12,13].

\section{Osteotomy in Clinical Practice}

According to Giraud et al. [14], osteotomies can be classified based on four criteria:

- $\quad$ End result

- Type

- Approach

- Incision site

The "end result" means the reason for performing the osteotomy, which can be specified as follows: (a) excision osteotomy for removal of a pathological piece of bone; (b) reparative osteotomy for anatomical correction and (c) osteotomy for approaching purpose, which consists in cutting a bone that obstructs access to the main operation site (for example, the tumor site) and then repositioning it in its anatomical location.

The "type" of osteotomy corresponds to the figure of the cut, for each of which a specific tool is designed.

Subperiosteal and extraperiosteal are the possible "approaches" to osteotomy, whereas the "incision site" localizes the bone region cut in long bones (epiphyseal, metaphyseal or diaphyseal) or in short/flat/irregular bones (carpus, skull, vertebrae, facial bones, et al.).

The goal of osteotomy surgery varies according to the surgical field considered.

Osteotomy or bone cutting is a widely standardized surgical procedure used for multiple purposes such as allowing access to malignancies, removing pathological bone fragments or realigning deformed bone segments.

Similarly, bone drilling is a complementary surgical technique mainly used in fracture fixation, allowing screw insertion [15]; moreover, it represents an essential step in joint [16] and oral [17] implantology. 
In orthopedic surgical correction of skeletal anomalies, osteotomies are performed broadly for two purposes: a simple osteotomy to acutely realign the axis of the bone and those techniques which allow bone lengthening or bone transport [2]. In orthopedic surgery, a short healing time is particularly important to avoid functional long-term complications (malconsolidation) [18].

In oncological and reconstructive surgery, osteotomy is commonly a mandatory step to access and remove bone or extraosseous malignancies as well as to grant both functional and aesthetic satisfactory reconstruction outcomes.

Most of the head and neck carcinomas involving the jaws require surgical osteotomy followed by adjuvant radiotherapy or concomitant chemoradiotherapy [19]. The effects of radiation on bone are well known and include alterations in the mineralized structure, alterations in the biomechanics of the collagen structure, a decrease in the number and qualitative osteogenic cell activity and cytokine alterations resulting in bone remodeling delay and damage [19]. However, few studies have focused on primary reconstruction followed by early irradiation but many of the currently available experimental models seem to be altered by radiation [19]. In the surgical reconstruction of mandibular bone defects with biomaterials, the early administration of radiation would seem to favor reabsorbing phenomena [20]. Similar experimental results on animal models have been found in the field of dental implantology [21,22]. Schon et al. [23] observed both significant quantitative and qualitative bone alterations with delayed initiation of bone formation after irradiation.

To guarantee cancer patients to receive adjuvant radiotherapy within the recommended times, it is important to achieve a good degree of bone healing in a short time after oncological and reconstructive surgery. In fact, considering that the normal time for secondary bone callus formation is around 4-6 weeks [24] and adjuvant radiotherapy should be ideally started within 42 days after surgery, it is easy to understand how a delay in bone healing implies a worse oncological prognosis [25].

\section{Osteotomy-Related Tissue Damage}

All surgical practices potentially expose the bone and surrounding tissues to damage. In particular, the tissue insult is mainly due to the heat produced by the friction generated between the osteotome saw or the drill bit and the bone [15].

It has been well established that, if the temperature exceeds the universally accepted danger threshold of $47^{\circ} \mathrm{C}$ for $1 \mathrm{~min}$ or more, thermal necrosis can be produced [15,16,26-28]. As the temperature and/or duration of the cutting procedure increases, the severity of the damage improves up to irreversibility $[15,28]$.

Thermal osteonecrosis substantially consists in bone cell death and subversion of endosteal architecture [27]. Specifically, immediate (within a few minutes) and delayed (within a few hours) effects of thermal shock can be recognized: the former consists of swelling and destruction of cell membranes and coagulation, with relative loss of blood flow leading to cell necrosis, whereas the latter refers to the activation of cellular signaling pathways that lead to apoptosis $[27,28]$. In both cases, an inflammatory response is always associated. The direct consequence of these events is the resorption of the bone around the screws or implants and its replacement with fibrous connective tissue [28].

Regarding the factors that influence the extent of heat production, there is currently widespread consensus that the main parameter is rotational speed; therefore, a higher speed number ( $\geq 3000 \mathrm{rpm})$ results in higher damage in terms of osteonecrosis [15]. Also relevant in this field are the drilling depth, the bone density and cortical thickness [29], the diameter of the drill bit and the pressure applied [30] and finally the one-step or graduated method of drilling [31,32].

Thermal osteonecrosis largely influences the patient's postoperative outcome, possibly causing screw-mediated bone fixation failure, nonunion or malunion, infections [27], implant loss and delayed healing [33].

Reasonably, cooling during surgical osteotomies or drilling procedures appears mandatory to avoid these complications. In this context, external irrigation with saline is the most common method 
adopted since Matthews and Hirsch have broadly demonstrated that it is the most effective cooling method of limiting excessive thermal increase [30].

To date, histology has represented the gold standard for the study (Table 1) of heat-related bone tissue necrosis since it allows an in situ analysis of the cells composing it [34]. Histomorphologically, the assessment of the extent of osteonecrosis is based on the osteocyte condition in the bone lacunae [15,35]; in fact, the death of these cells in the pathological bone is documented by the empty appearance of the lacunae [35]. Bentolila et al. found that osteocyte damage develops through four stages: (1) normal osteocyte, (2) shrunken osteocyte, (3) osteocyte with pyknotic nucleus and (4) empty lacunae [36].

Table 1. Main investigations for heat-related bone tissue necrosis.

\begin{tabular}{|c|c|c|}
\hline Cytology and Histology & $\begin{array}{l}\text { Molecular Biology and } \\
\text { Biochemistry }\end{array}$ & Physics \\
\hline $\begin{array}{l}\text { Histologic parameters } \\
\text { - } \quad \text { cell composition } \\
\text { - } \quad \text { blood clot and vessels } \\
\text { - } \quad \text { connective tissue, bone neoformation, } \\
\text { microcracks, lacunae, bridges }\end{array}$ & $\begin{array}{l}\text { PCR } \\
\text { BMP, Wnt, osteogenesis, } \\
\text { inflammatory cytokines, } \\
\text { apoptosis, growth-factors; } \\
\text { Hsp70 }\end{array}$ & $\begin{array}{l}\text { Temperature rise } \\
\text { - } \quad \text { thermocouples } \\
\text { - } \quad \text { infrared thermography } \\
\text { - } \quad \text { thermosensors } \\
\text { - } \quad \text { fiber optic thermometer }\end{array}$ \\
\hline $\begin{array}{l}\text { Histomorphometric } \\
\text { and Micromorphometric Analysis }\end{array}$ & $\begin{array}{l}\text { ELISA } \\
\text { test on the perisulcular fluid to } \\
\text { search for RANKL and OPG } \\
\text { levels }\end{array}$ & Micro-CT \\
\hline $\begin{array}{l}\text { Immunohistochemistry } \\
\text { - } \quad \text { VEGF, CAS3, OPG, RANKL, OC, NADH2 } \\
\text { and NADPH2, diaphorase activity }\end{array}$ & & СBCT \\
\hline Scanning electron microscopy (SEM) & & Laser 3D scanning \\
\hline Transmission electron microscopy (TEM) & & Laser profilometry \\
\hline Intravital microscopy & & \\
\hline
\end{tabular}

BMP: Bone Morphogenetic Protein.

However, it has recently been shown that histological/histomorphological investigation techniques do not allow us to grasp the micro-mechanical damage induced by bone cutting surgeries within the drilled sub-surface. Using micro-mechanical investigations such as compression and tensile tests and microhardness, it has been revealed that micro-mechanical bone damage assessment is particularly important [37]. It is plausible that high temperatures during surgical cutting or drilling imply greater damage also in terms of elastic and plastic property alterations of the surrounding non-necrotic bone tissue.

Considering that the bone remodeling process closely depends on the applied functional loads [38], the lower mechanical resistance together with the thermal necrosis could have significant repercussions for the post-surgical healing of osteotomies.

Finally, it is necessary to underline that micro-crack (micro-fractures) formation in the adjacent bone to the cutting or drilling site constitutes another possible complication to consider [39] in clinical practice. The consequence can be prosthetic or bone failure. This risk would appear to be greater if blunt/worn tips are used [16,40].

\section{How Bone Healing Occurs after Bone Injury}

Bone healing is the process that restores the anatomy and function of bone after injury (fracture or osteotomy); it can be divided into primary and secondary healing based on differences in the mobility between the fracture fragments [41,42].

Primary healing happens when bone injured surfaces are juxtaposed and fixed through surgery and bone remodeling through the original fracture line leads to bone healing. Secondary healing takes place in all other circumstances and is usually divided into four stages that partially overlap each other. 
The first stage is called the "inflammatory stage": after injury, bone blood vessels release blood within the fracture site and hematoma develops between bone fragments. This lasts a few days and is characterized by pain and swelling. The lack of blood supply to adjacent bone leads to bone necrosis that is characterized histologically by empty osteocyte lacunae. After blood clot formation, cytokines (such as PDGF, TGF- $\beta 1$, VEGF, PGE1 and E2) released from platelets and mast cells stimulate neoangiogenesis and the formation of a granulation tissue that replaces the blood clot. Mononuclear phagocytes derived from new vessels assist the removal of necrotic bone and blood clots and aid the construction of the soft callus that will follow. Macrophages are also believed to play a fundamental role in fracture repair since they secrete several growth factors, such as fibroblast growth factor (FGF) that initiates fibroplasia both in soft tissue as well as in bone repair [43].

The second stage is called the "soft callus stage": it is characterized by a fibrous tissue whose cells are derived from endosteum, periosteum, bone marrow and adjacent soft tissues. From this stage on, a recapitulation of bone histogenesis occurs, leading to the third stage, called the "hard callus stage", whose progression strictly depends on the presence of blood supply.

If a good blood supply is present, new osteoblasts differentiate and start to lay down the bone matrix during "intramembranous ossification". During intramembranous ossification, both in physiological organogenesis and in pathologic conditions, it has been demonstrated for the first time $[8,44-47]$ that two different processes of bone formation exist, occurring in sequence, named static osteogenesis (SO) and dynamic osteogenesis (DO). SO is characterized by pluristratified cords of "stationary" osteoblasts which differentiate by inductive stimuli [48-51] at roughly constant distance from the capillaries (without moving during their transformation into osteocytes from the differentiation site); otherwise, DO is performed by the typical monostratified laminae of "movable" osteoblasts. The following events occur in sequence: firstly, variously polarized stationary osteoblasts (irregularly arranged inside cords) give rise, in the same place where they differentiate, to osteocytes (clustered within confluent lacunae), thus allowing the formation of preliminary thin trabeculae made up of woven bone that, due to their too-high cellularity, are not effectual from a mechanical viewpoint. Afterwards, along the surfaces of the SO-trabecular preliminary framework, dynamic osteogenesis occurs, which is mostly involved in filling primary haversian spaces, thus giving rise to primary osteons. DO-bone consists in lamellar bone which is mechanically more resistant compared to SO-trabecular bone, since it is less cellularized and arranged in a more orderly pattern; moreover, it occurs in relation to mechanical stimuli, instead of inductive vascular-derived factors (as occurs for $\mathrm{SO}$ ).

On the contrary, if a blood supply deficiency occurs, thus leading to low local oxygen rate, cartilage may form within the fibrous tissue; eventually, the cartilage, after hypertrophy and calcification, will be replaced by bone, as in endochondral ossification. In the case of bone repair by endochondral ossification, SO never seems to take place. In fact, the osteoblasts in contact with the remnants of the calcified cartilage are directly arranged in movable laminae [52] and all appear to be functionally polarized in the same direction, i.e., toward the calcified cartilage. Thus, in endochondral ossification, $\mathrm{DO}$ is not preceded by SO.

At the end of the third stage, independently of the type of ossification (intramembranous or endochondral), the new bone that bridges the bone fragments is usually wider than the original bone profile. Once mechanical integrity has been re-established, the "remodeling stage" of the hard callus takes place. This represents the last stage of bone healing, which may lead to the recovery of the original anatomical shape. The balanced action of osteoclastic resorption and osteoblastic deposition is governed by Wolff's law and modulated by piezoelectricity, a phenomenon in which electrical polarity is created by pressure exerted in a crystalline environment [53].

\section{Which Animal Model Is Suitable for Bone Investigation of Osteotomic Effects?}

A great variety of animal models are present in the scientific literature (Table 2) for investigations of bone effects after osteotomy. As shown in Table 2, there are many similarities and differences regarding bone parameters concerning animal species, and between animals and humans, at the 
same time. As if it were an aphorism, we can say that the animal model that most resembles human bone features is ... the human being! In fact, no animal can perfectly mimic all the static and dynamic human bone characteristics [54]. Given the obvious ethical implications, studies of bone healing or bone damage on humans are very difficult. Nevertheless, investigations can be done by an indirect evaluation - for example, observing the biochemical values in the peri-implant sulcular fluid, the radiologic exams or certain protein (such as Hsp-70) expression in bone specimens collected immediately after an osteotomy $[55,56]$.

Table 2. Main animal models for bone healing investigation [54,57-65].

\begin{tabular}{|c|c|c|c|c|}
\hline Animal & $\begin{array}{l}\text { Bone Microscopic and } \\
\text { Macroscopic Features }\end{array}$ & $\begin{array}{l}\text { Bone Composition } \\
\text { and Remodeling }\end{array}$ & Animal Management & Best Type of Study \\
\hline Rodents & $\begin{array}{l}\text { Mainly primary bone } \\
\text { in long bone cortices } \\
\text { and minimal } \\
\text { cancellous bone. } \\
\text { Cortices are thin and } \\
\text { fragile. }\end{array}$ & $\begin{array}{l}\text { Limited cortical } \\
\text { remodeling and } \\
\text { non-Haversian-type } \\
\text { remodeling. Limited } \\
\text { secondary osteon } \\
\text { formation. Higher } \\
\text { bone healing capacity } \\
\text { in craniofacial bones. }\end{array}$ & $\begin{array}{l}\text { Cheap and easily } \\
\text { manageable. Rats are } \\
\text { more docile and social } \\
\text { than mice, although } \\
\text { the latter are cheaper } \\
\text { to house and maintain. }\end{array}$ & $\begin{array}{c}\text { Osteoinduction. } \\
\text { Cartilage regeneration } \\
\text { potential. Bone } \\
\text { infection. Extraoral } \\
\text { surgical approaches. }\end{array}$ \\
\hline Rabbit & $\begin{array}{l}\text { Cortices are fragile and } \\
\text { there is less cancellous } \\
\text { bone than in humans. } \\
\text { Quick achievement of } \\
\text { skeletal maturity. } \\
\text { Small size. Lack of } \\
\text { biomechanical data. } \\
\text { Dense Haversian bone. }\end{array}$ & $\begin{array}{l}\text { Similar bone density to } \\
\text { human. Bone } \\
\text { metabolism is similar } \\
\text { to human, with } \\
\text { Haversian-type } \\
\text { remodeling, although } \\
\text { with a higher rate than } \\
\text { humans. }\end{array}$ & $\begin{array}{l}\text { Availability, housing } \\
\text { and handling are easy. } \\
\text { Cage confinement } \\
\text { might worsen their } \\
\text { bone healing } \\
\text { capability. }\end{array}$ & $\begin{array}{l}\text { Muscolo-skeletal } \\
\text { research. Bone } \\
\text { implants. Modeling of } \\
\text { vertebral fracture } \\
\text { repair. Extraoral } \\
\text { surgical approaches. }\end{array}$ \\
\hline Sheep & $\begin{array}{l}\text { High trabecular bone } \\
\text { density. Good body } \\
\text { weight. Different bone } \\
\text { microstructure than } \\
\text { humans. Big difference } \\
\text { between young and } \\
\text { mature sheep due to } \\
\text { age-dependent } \\
\text { changes in bone } \\
\text { structure. }\end{array}$ & $\begin{array}{l}\text { Similar bone healing } \\
\text { capability to humans. } \\
\text { Different remodeling } \\
\text { processes. }\end{array}$ & $\begin{array}{l}\text { Although docile, their } \\
\text { size requires a lot of } \\
\text { space. }\end{array}$ & $\begin{array}{l}\text { Orthopedic research. } \\
\text { Bone filler materials in } \\
\text { cranial osteotomies. } \\
\text { Extraoral surgical } \\
\text { approaches. }\end{array}$ \\
\hline Goats & $\begin{array}{l}\text { Good size. Presence of } \\
\text { Haversian systems in } \\
\text { the tibia, except for the } \\
\text { caudal part. }\end{array}$ & $\begin{array}{l}\text { Similar bone healing } \\
\text { potential. Similar bone } \\
\text { composition. }\end{array}$ & $\begin{array}{l}\text { Docile and tolerant to } \\
\text { environmental } \\
\text { conditions. A lot of } \\
\text { space is needed. }\end{array}$ & $\begin{array}{c}\text { Bone filler materials in } \\
\text { cranial osteotomies. } \\
\text { Extraoral surgical } \\
\text { approaches. Cartilage, } \\
\text { ligaments and menisci } \\
\text { regeneration. }\end{array}$ \\
\hline Pig & $\begin{array}{l}\text { Plexiform bone, which } \\
\text { shifts to dense } \\
\text { secondary osteonal } \\
\text { bone. Good } \\
\text { development of the } \\
\text { Haversian system, } \\
\text { with medium canals. } \\
\text { Similar to humans. }\end{array}$ & $\begin{array}{l}\text { Similar bone density } \\
\text { and bone mineral } \\
\text { concentration. Similar } \\
\text { bone remodeling. }\end{array}$ & $\begin{array}{l}\text { High body weight and } \\
\text { aggressive nature. }\end{array}$ & $\begin{array}{l}\text { Extra- and intraoral } \\
\text { approaches. } \\
\text { Osteonecrosis surgery. } \\
\text { Osteogenic } \\
\text { regeneration materials } \\
\text { in craniofacial bones. } \\
\text { Dental implants. }\end{array}$ \\
\hline
\end{tabular}


Table 2. Cont.

\begin{tabular}{ccccc}
\hline Animal & $\begin{array}{c}\text { Bone Microscopic and } \\
\text { Macroscopic Features }\end{array}$ & $\begin{array}{c}\text { Bone Composition } \\
\text { and Remodeling }\end{array}$ & Animal Management & Best Type of Study \\
\hline Dog & $\begin{array}{c}\text { Similar cancellous } \\
\text { bone to humans. } \\
\text { Presence of secondary } \\
\text { osteons with small } \\
\text { canals. Thinner } \\
\text { articular cartilage. }\end{array}$ & $\begin{array}{c}\text { Variability of } \\
\text { trabecular bone } \\
\text { remodeling depending } \\
\text { on site, age and } \\
\text { species. }\end{array}$ & $\begin{array}{c}\text { Docile, easy handling. } \\
\text { Good size. }\end{array}$ & $\begin{array}{c}\text { Dental implants and } \\
\text { peri-implantitis. }\end{array}$ \\
\hline $\begin{array}{l}\text { Non-human } \\
\text { primates }\end{array}$ & Close to humans. & $\begin{array}{c}\text { Comparable to } \\
\text { humans. }\end{array}$ & $\begin{array}{c}\text { Difficult to handle and } \\
\text { highly trained staff are } \\
\text { needed. }\end{array}$ & Bone implant. \\
\hline
\end{tabular}

However, animal models are invaluable in the study of bone healing (Table 3). The European Commission stressed their central role and "the three Rs" have been established as the fundamental pillars of animal experimentation:

- Reduction: the number of animals involved must be the lowest necessary to achieve scientific evidence;

- Refinement: animals' suffering must be kept to a minimum;

- Replacement: if it is possible, a non-animal-based study is preferred [66,67].

Table 3. Advantages and disadvantages according to different times of euthanasia in animal models.

\begin{tabular}{|c|c|c|}
\hline & Advantages & Disadvantages \\
\hline Ex vivo & $\begin{array}{c}\text { Low costs } \\
\text { No need for ethical approval } \\
\text { Amount of information on bone damage } \\
\text { Reproducible conditions } \\
\text { Large numbers }\end{array}$ & $\begin{array}{l}\text { Only hypotheses regarding } \\
\text { possible clinical correlations } \\
\text { Less realistic setting }\end{array}$ \\
\hline $\begin{array}{l}\text { In vivo and } \\
\text { immediate } \\
\text { sacrifice }\end{array}$ & $\begin{array}{l}\text { Evaluation of bone damage in an in vivo scenario } \\
\text { Possibility to obtain baseline results to compare } \\
\text { with delayed sacrifice in in vivo results }\end{array}$ & $\begin{array}{l}\text { Impossible to perform bone } \\
\text { healing evaluations } \\
\text { Intermediate costs }\end{array}$ \\
\hline $\begin{array}{c}\text { In vivo and } \\
\text { delayed sacrifice }\end{array}$ & $\begin{array}{c}\text { Bone healing evaluation, with the possibility to } \\
\text { obtain both static and dynamic evaluation of } \\
\text { osteotomic gap } \\
\text { Wide range of parameters to be analyzed } \\
\text { Closer to clinical setting in humans }\end{array}$ & $\begin{array}{c}\text { High costs } \\
\text { Small numbers } \\
\text { Small animal to respect animal } \\
\text { testing hierarchy and ethics on } \\
\text { animals }\end{array}$ \\
\hline
\end{tabular}

These rules are imperative for an in vivo animal model. As far as the last point (replacement) is concerned, it has to be said that ex vivo studies (with bone segments provided by commercial slaughter) are suitable to evaluate osteotomic bone damage. Some authors also proposed artificial bone specimens derived from bovine bone due to its thermal conductivity, which is similar to human bone $[68,69]$. Altogether, a cost-benefit evaluation of the considered experimentation has to prove the potential for progress in human or animal health over the damage caused to the animals [54]. According to our experience, study-specific criteria must be considered as well. The aspects to take into consideration are:

- The type and the aim of the study

- The osteotomy device used.

The aim of the study has a central role in the correct choice of animal model: when the purpose is to study the osteointegration of endosseous dental implants, its size has to comply with animal and 
bone-specific principles [59]. The same rule must be applied to the choice of osteotomy device: a large device must be used on adequately sized bones.

Together with these general principles, the choice of a proper animal model has to be influenced by other animal-specific criteria for bone:

- The specific bone site and its characteristics (femur, tibia, calvaria, mandible, vertebra)

- Bone macroscopic and microscopic features, including size and biomechanical properties

- Bone composition and density

- Bone turnover rates

- Specific conditions for bone healing, such as the critical size defect

- Costs and aspects regarding the management of the animal (including acquisition costs, housing costs and the need for specifically trained staff).

In particular, the economical and managerial aspects of animal experimentation have to be underlined. If a small animal model is possible, a larger animal model is to be considered unjustifiable according to Ethics in Animal Research Guidelines: (i) small animals before larger ones have to be selected to respect the animal testing hierarchy (European Communities Council Directive of 23 September 2010 [2010/63/EU]; (ii) compliance must be ensured with the Italian laws for the protection of animals used for scientific purposes (Decree Law No 61 of 4 March 2014) [70].

A particular animal can be highly suitable for a study because of its bone features, but there might not be a funding, logistic or training basis to proceed to the experimentation. At the same time, small animals such as rodents are often suitable in terms of feasibility, but they might not match the needed osseous characteristics, especially because of their small size.

Considering all the possible elements, the ideal animal models are non-human primates (NHPs), followed by dogs, although the ethical issues raised recently have made their involvement in animal experimentation increasingly difficult [71]. Nevertheless, it has to be considered that in vivo experimentation does not always imply the sacrifice of the animal-for example, in the case of an evaluation of microcirculatory parameters with intravital microscopy [72].

Bone macroscopic and microscopic characteristics deeply influence the choice of animal model: rodent bones can hardly be a suitable model for developing a novel dental implant, due to their small size. On the contrary, notwithstanding their dimensions, murine models can provide insights into the processes that underlie the biocompatibility of biomaterials [73-75] and bone healing, also based on multiple specific strains that have been selected over time [60,76].

Larger animals have many more clinical, biomechanical and dimensional similarities to humans. This is reflected also by the different bone turnover rates, which are close to the human ones in dogs or pigs and are much quicker in rodents and rabbits. Therefore, they can be crucial to study the steps and the clinical aspects of bone healing.

A question to be raised is whether a specific animal bone site (i.e., a specific region of a particular skeletal segment) is more suitable than another one in the study to obtain inferences about a specific human bone site. The most used sites in animal models are the femur, tibia, calvaria, mandible and vertebra, and each one has particular features that vary depending on the animal. A great variety of properties has to be considered in different subsites within the same bone, in term of bone density and cortico/cancellous thickness; for example, anterior and posterior mandible specimens show peculiar characteristics, as well as femoral diaphysis, metaphysis, epiphysis, et al. To our knowledge, there is no clear evidence in the scientific literature of the better adequacy of a specific anatomic site in an animal model for speculation about a human bone site. The investigator has to take into consideration all the above-mentioned aspects.

For instance, we chose as an animal model the in vivo rabbit calvaria in our previous paper [8], considering: 
- The osteotomy instruments that we wanted to test (two different piezosurgical devices and one conventional rotary osteotomy device), which required high dense bone. We consequently excluded mice, dog alveolar bone and rabbit mandible or femur.

- The space that we needed in order to perform several osteotomic lines, which helped us in lowering the number of animals to sacrifice and led us to exclude mouse or rat as potential animal models due to their small size (Reduction in "the three Rs" [70]);

- The European Communities Council Directive, which led us to exclude large animal models (sheep, pork, dog) on an ethical basis [8].

\section{Osteotomic Investigation with Rotational Instrument and Piezosurgical Devices: Our Experience}

In 2018, we performed a study [8] on an animal model to evaluate, in 16 six-month-old white New Zealand rabbits, bone regeneration after osteotomy. The experimental procedures were executed in accordance with the Bioethical Committee of the Italian National Institute of Health and authorized with Decrees of the Italian Ministry of Health (protocol number 210/2013-B). Surgical procedures and animal care and maintenance were performed according to Italian law (D.L. no. 26/2014) and European legislation (EEC no. 63/2010).

The aim of the study was to compare bone healing dynamics in experimental osteotomies, using two piezosurgical devices with different output power (Piezosurgery ${ }^{\circledR}$ Medical and Piezosurgery ${ }^{\circledR}$ Plus) and a conventional rotary osteotome, in an in vivo rabbit model. The null hypothesis stated that there would be no difference in bone healing among the three devices employed.

Four couples of linear craniotomies $(1 \mathrm{~cm}$ in length-full thickness cut of the calvaria preserving the dura mater) were carried out by the same surgeon in each rabbit skull, using different surgical osteotomic systems: (a) conventional rotary bur (RO); (b) Piezosurgery ${ }^{\circledR}$ Medical (PM) and (c) Piezosurgery ${ }^{\circledR}$ Plus (PP), both provided by Piezosurgery ${ }^{\circledR}$ - Mectron Medical Technology, (Carasco, Italy). PP is characterized by a higher output power ( $75 \mathrm{~W})$ compared to PM (23 W) (Figure 1). The fascia-periosteal flaps and skin were eventually sutured. Two weeks after surgery, bone fragments were harvested and processed for histological and histomorphometric analyses as well as for scanning electron microscopy (SEM) investigations.

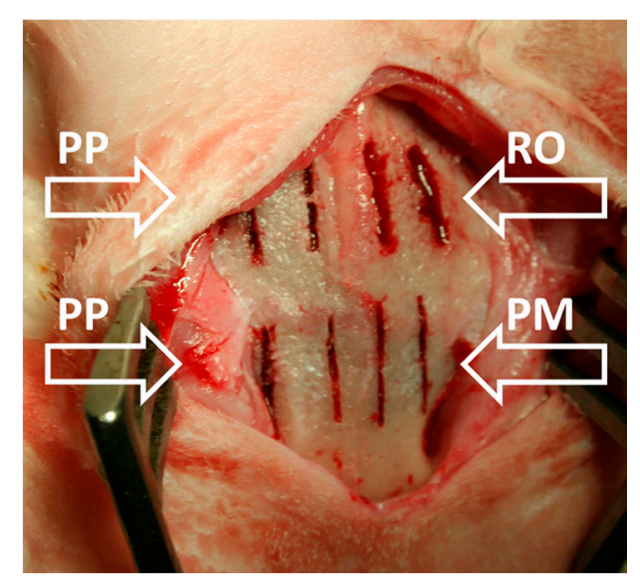

Figure 1. Gross photograph showing the osteotomies performed in each rabbit skull: two by means of rotary bur (RO), two by means of Piezosurgery ${ }^{\circledR}$ Medical (PM), and four by means of Piezosurgery ${ }^{\circledR}$ Plus (PP) (as indicated by arrows).

Results showed that osteotomies performed by means of both piezoelectric devices (PM and PP) produce half-sized bone gaps with respect to those produced by RO (Figure 2). 

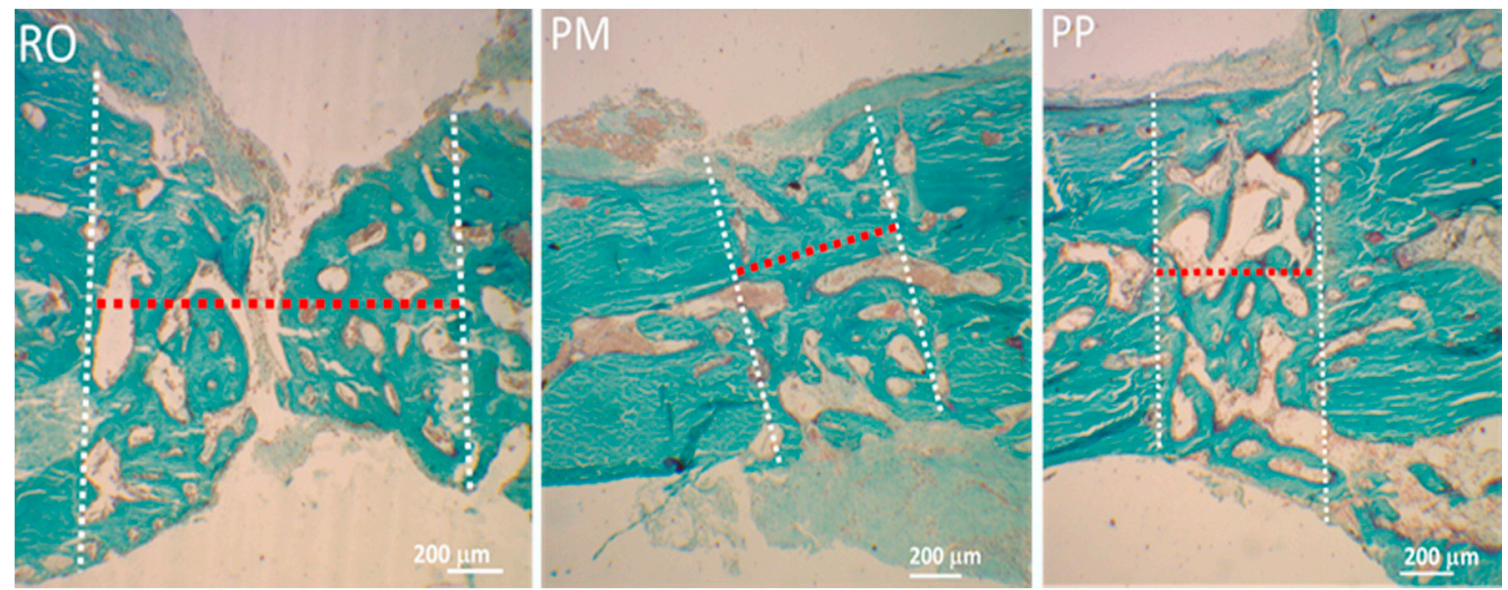

Figure 2. Light microscope (LM) micrographs showing the thickness (red dotted line) of the osteotomy (between the two white dotted lines) obtained using the three different devices (RO, PM, PP), producing different bone gaps. Note that the RO device produces a gap around twice the width of those produced by PM and PP. Perivascular stromal spaces among the bone-forming trabeculae appear wider in RO osteotomy.

Larger amounts of fibrous tissue (soft callus stage) with respect to bone tissue were present in RO samples than in PM and PP ones (Figure 3).
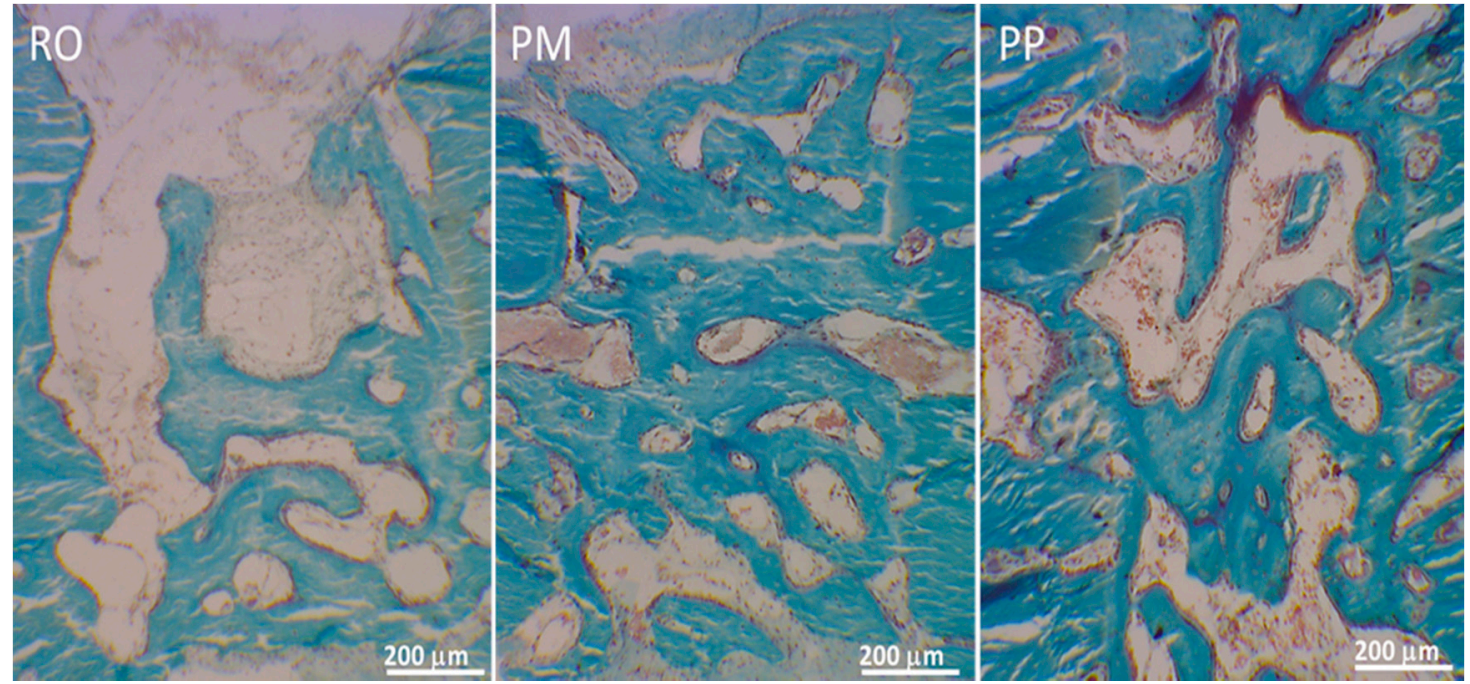

Figure 3. LM micrographs showing in three different osteotomies the newly formed bone during gap recovery.

Close to the forming bony trabeculae, numerous static osteoblasts arranged in cords and involved in preliminary bone regeneration were observed in RO samples; on the contrary, in PM and PP samples, bony trabeculae were mostly covered by typical prismatic dynamic osteoblasts arranged in monostratified laminae and involved in bone compaction (hard callus stage) (Figure 4). 

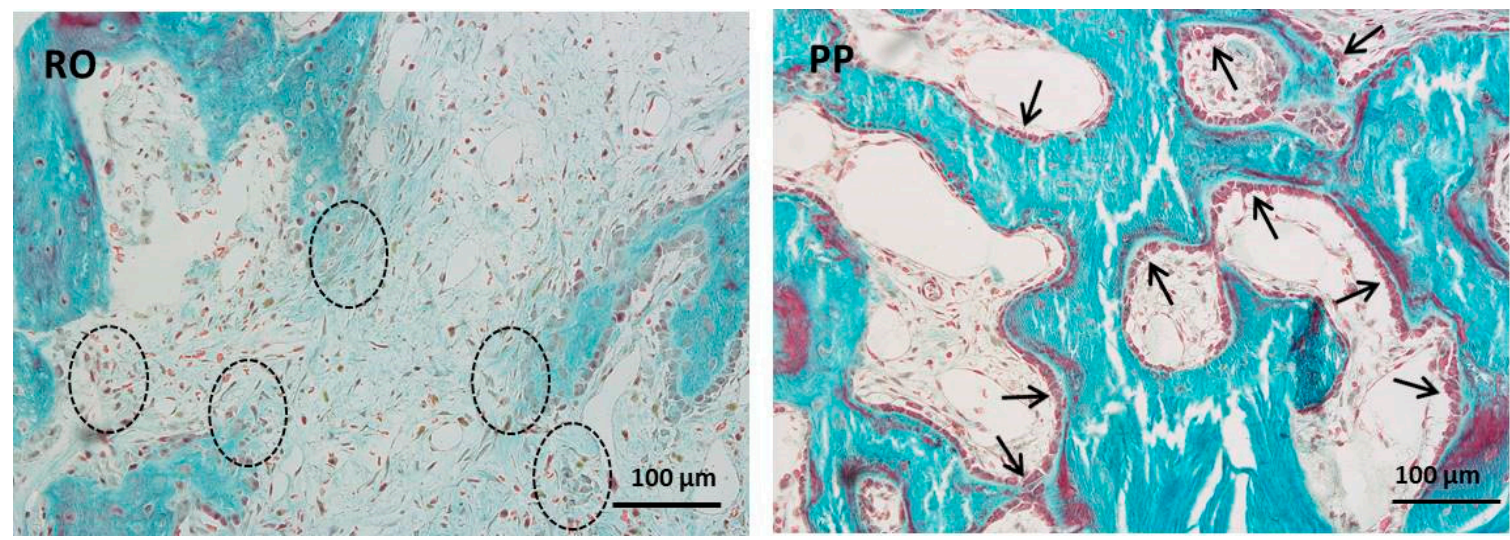

Figure 4. LM micrographs showing osteoblasts arranged in cords (dashed ovals) in RO. Arrows indicate osteoblastic laminae in PP field. It is also to be underlined that in the thinner PM/PP bone gaps, the osteoblasts are in more favorable conditions (i.e., a suitable distance from the capillaries) so that they more easily obtain the vascular derived inductive factors that, in turn, allow the progression from static to dynamic osteogenesis; as a consequence, a lower amount of fibrous tissue is observed in PM and PP with respect to $\mathrm{RO}$.

Independently of the device used, in all osteotomies, backscattered SEM analysis showed, as expected, that the newly formed bony trabeculae inside the osteotomy gap were less mineralized with respect to the adjacent pre-existing bone; moreover, the regenerated bone was characterized by higher cell density with respect to the pre-existing bone. It is possible to observe inside the healing gap, only in RO osteotomies, the presence of some fragments/remnants of osteotomized bone, absent in PM and PP osteotomies (Figure 5).
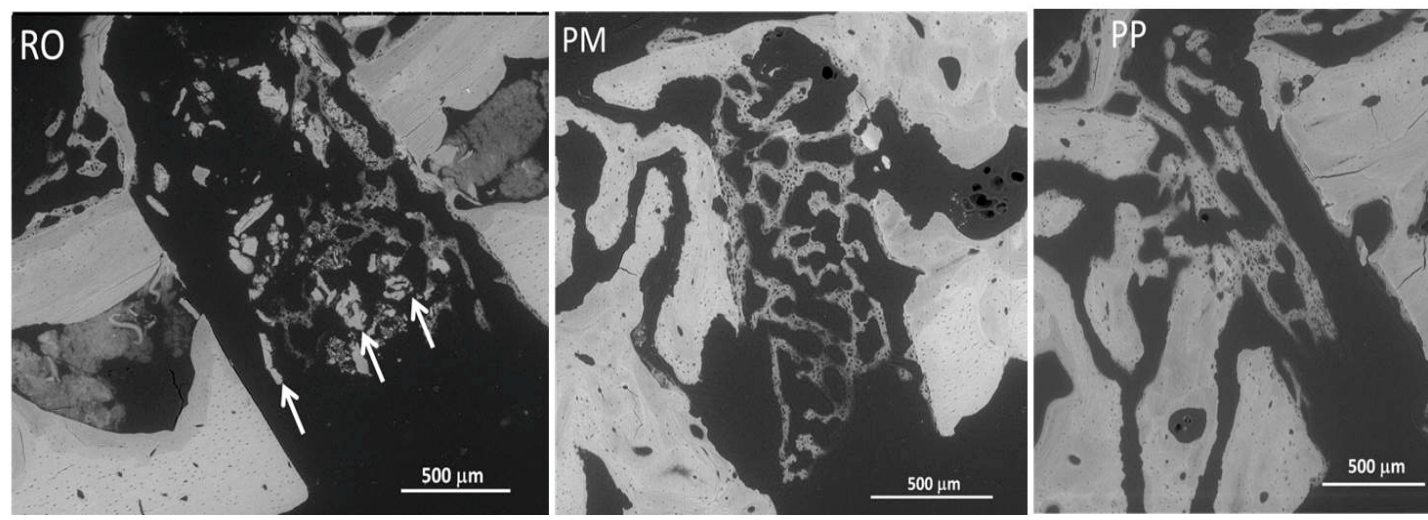

Figure 5. SEM micrographs showing in RO, PM, and PP samples the lower mineralization and higher cell density in the newly formed bony trabeculae inside the osteotomy gaps, compared to the adjacent pre-existing native bone. Some fragments/remnants of osteotomized bone are only present in RO osteotomies (arrows).

As far as bone regeneration is concerned (remodeling stage), the better performance of modern devices with respect to the traditional ones is also sustained by increased bone remodeling in PM and PP; in fact, a significantly higher osteoclast number (marked by tartrate-resistant acid phosphatase (TRAP) reaction) was observed within the gaps in PM and PP osteotomies with respect to RO ones, particularly concerning PP vs. RO (Figure 6). 

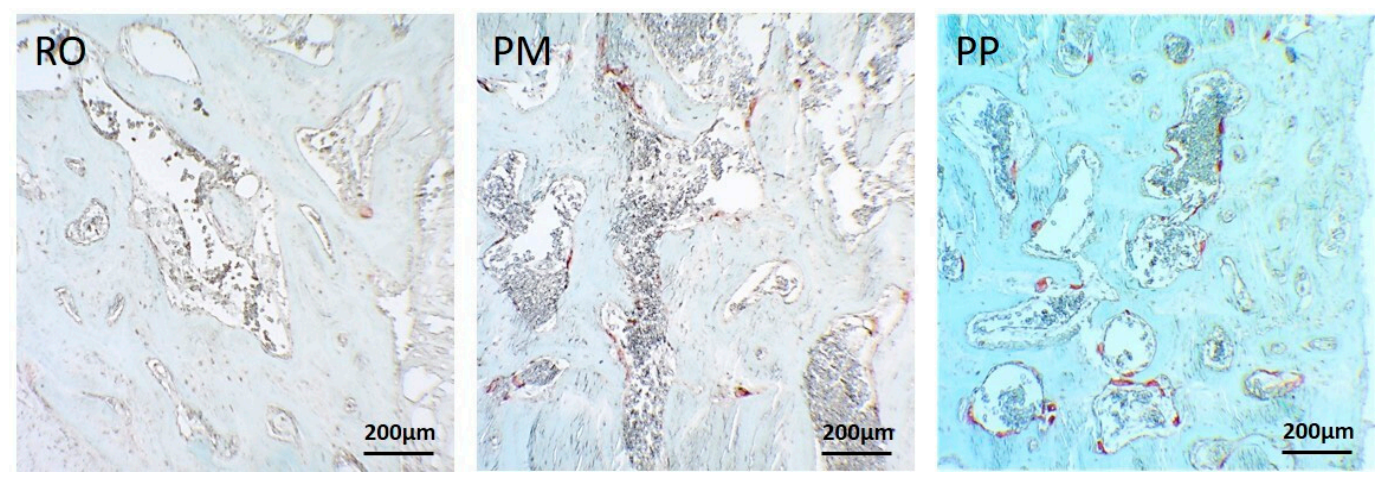

Figure 6. LM micrographs showing tartrate-resistant acid phosphatase (TRAP) reaction in the three osteotomies; in PM and PP osteotomies, the positivity (red color) is higher compared with RO.

To better explain, it is to be remembered that bone remodeling requires preliminary osteoclast differentiation/activation, in turn triggering the cells of the reversal phase (probably of stromal-fibroblast origin) that induce osteoblast differentiation, so that bone formation can occur to improve bone quality [77]. Besides the influence of an osteotomy device on bone regeneration, it is not of secondary importance its potential injury of bone cells near the edge of the osteotomy; our results show viable osteocytes closer to the osteotomy edge in bone cut by piezoelectric devices (in particular, concerning PP vs. PM) with respect to the traditional ones.

Finally, our findings demonstrate that PM and PP produce thinner bone gaps, in turn easier and faster to be recovered, with respect to $\mathrm{RO}$ osteotomies, where all healing processes require longer times. Therefore, piezosurgery is more effective than the conventional techniques in improving the progression of skeletal repair. According to these results, the null hypothesis that there would be no difference in bone healing among the three devices could be rejected.

\section{What Kind of Information Can We Obtain from In Vivo and Ex Vivo Studies of Osteotomy?}

Analyzing the scientific literature, great heterogeneity in the materials and methods utilized for studying osteotomic effects can be noted (Table 4).

Table 4. Main animal studies on osteotomic damage available in the scientific literature.

\begin{tabular}{|c|c|c|c|c|c|}
\hline Author & Animal Model & Type of Study & $\begin{array}{l}\text { Material and } \\
\text { Methods }\end{array}$ & $\begin{array}{l}\text { Osteotomy } \\
\text { Device }\end{array}$ & Conclusions \\
\hline $\begin{array}{c}\text { Moss, } 1964 \\
{[78]}\end{array}$ & Dog mandible & Ex vivo & $\begin{array}{l}\text { Ocular } \\
\text { micrometer }\end{array}$ & $\begin{array}{l}\text { Rotary cutting } \\
\text { device set at } \\
\text { three different } \\
\text { speed ranges }\end{array}$ & $\begin{array}{l}\text { Ultra-high-speed cutting did } \\
\text { not produce higher bone } \\
\text { damage than lower speed } \\
\text { mode, especially when used } \\
\text { with adequate coolants. } \\
\text { Cooling agents reduced } \\
\text { bone damage. }\end{array}$ \\
\hline $\begin{array}{c}\text { Spatz, } 1965 \\
\text { [79] }\end{array}$ & Dog jaw & $\begin{array}{c}\text { In vivo } \\
\text { The animals were } \\
\text { sacrificed at } 1,2 \text { and } \\
7 \text { days } \\
\text { postoperatively }\end{array}$ & $\begin{array}{c}\text { Photomicrog } \\
\text { raphy }\end{array}$ & $\begin{array}{l}\text { Rotating burs } \\
\text { at conventional } \\
\text { and high speed. }\end{array}$ & $\begin{array}{l}\text { Ultra-high-speed } \\
\text { osteotomies showed better } \\
\text { and quicker bone healing } \\
\text { and smoother cut edge } \\
\text { compared to conventional } \\
\text { speed burs, particularly } \\
\text { evident } 1 \text { week after the } \\
\text { surgical procedure. }\end{array}$ \\
\hline $\begin{array}{c}\text { Horton et al., } \\
\text { 1975. [80] }\end{array}$ & $\begin{array}{c}\text { Dog alveolar } \\
\text { bone }\end{array}$ & $\begin{array}{c}\text { In vivo. } \\
\text { The animals were } \\
\text { sacrificed } \\
\text { immediately after the } \\
\text { surgical procedure } \\
\text { and at } 3,7,14,28,56 \\
\text { and } 90 \text { days } \\
\text { postoperatively. }\end{array}$ & $\begin{array}{l}\text { Light } \\
\text { microscope }\end{array}$ & $\begin{array}{l}\text { Ultrasonic } \\
\text { instrument, } \\
\text { low-speed } \\
\text { rotary cutting } \\
\text { bur and } \\
\text { surgical chisel }\end{array}$ & $\begin{array}{l}\text { The bur produced the } \\
\text { smoothest surface. Healing } \\
\text { in later periods appeared } \\
\text { histologically to be the best } \\
\text { with the use of the surgical } \\
\text { chisel. After } 90 \text { days, the } \\
\text { bone healing was complete. }\end{array}$ \\
\hline
\end{tabular}


Table 4. Cont.

\begin{tabular}{|c|c|c|c|c|c|}
\hline Author & $\begin{array}{l}\text { Animal } \\
\text { Model }\end{array}$ & Type of Study & $\begin{array}{l}\text { Material and } \\
\text { Methods }\end{array}$ & $\begin{array}{l}\text { Osteotomy } \\
\text { Device }\end{array}$ & Conclusions \\
\hline $\begin{array}{l}\text { Eriksson et al., } \\
1984 \text { [81] }\end{array}$ & $\begin{array}{l}\text { Rabbit femur, } \\
\text { fibula and } \\
\text { tibia }\end{array}$ & $\begin{array}{l}\text { In vivo. } \\
\text { Animals in the first } \\
\text { group were sacrificed } \\
\text { immediately after the } \\
\text { surgical procedure. } \\
\text { Half of the animals } \\
\text { of the second group } \\
\text { were sacrificed } 1 \\
\text { week after the } \\
\text { thermic damage, } \\
\text { while the other half } \\
\text { were followed up for } \\
17 \text { weeks. }\end{array}$ & $\begin{array}{l}\text { Histology, } \\
\text { histochemistry and } \\
\text { vital microscopy. }\end{array}$ & $\begin{array}{l}\text { Twist driller, } \\
\text { thermostatically } \\
\text { heated saline } \\
\text { solution and } \\
\text { thermal } \\
\text { chamber }\end{array}$ & $\begin{array}{l}\text { Histochemistry provides } \\
\text { a better evaluation of } \\
\text { bone viability after } \\
\text { heat-induced trauma } \\
\text { than histology. Vital } \\
\text { microscopy is more } \\
\text { sensitive in the } \\
\text { evaluation of bone } \\
\text { healing following heat } \\
\text { trauma than indirect, } \\
\text { histological and } \\
\text { histochemical methods. }\end{array}$ \\
\hline $\begin{array}{c}\text { Wächter and } \\
\text { Stoll, } 1991 \\
\text { [82] }\end{array}$ & $\begin{array}{l}\text { Bovine and } \\
\text { sheep } \\
\text { mandible }\end{array}$ & $\begin{array}{l}\text { Both in vivo and ex } \\
\text { vivo } \\
\text { The animals were not } \\
\text { sacrificed. }\end{array}$ & Thermocouples & Oscillating saw & $\begin{array}{l}\text { Only the combination of } \\
\text { intermittent sawing and } \\
\text { irrigation allows a safe } \\
\text { osteotomy from a } \\
\text { thermic point of view. }\end{array}$ \\
\hline $\begin{array}{l}\text { Abouzgia } \\
\text { and } \\
\text { Symington, } \\
1996 \text { [83] }\end{array}$ & Bovine femur & Ex vivo & $\begin{array}{c}\text { K-type } \\
\text { thermocouple } \\
\text { (Omega) }\end{array}$ & $\begin{array}{l}\text { Surgical drill } \\
\text { (Stryker-100) }\end{array}$ & $\begin{array}{l}\text { Drilling at high speed } \\
\text { and large load seems to } \\
\text { provide a better } \\
\text { combination in terms of } \\
\text { temperature rise and } \\
\text { duration of temperature } \\
\text { elevation. }\end{array}$ \\
\hline $\begin{array}{l}\text { Keijser et al., } \\
1999 \text { [84] }\end{array}$ & $\begin{array}{l}\text { Rabbit tibia } \\
\text { and femur }\end{array}$ & $\begin{array}{l}\text { In vivo } \\
\text { The animals in the } \\
\text { first group were } \\
\text { sacrificed after } 1 \\
\text { week. } \\
\text { The animals in the } \\
\text { second group were } \\
\text { sacrificed after } 1,3,5 \text {, } \\
\text { 7,9 and } 12 \text { weeks. }\end{array}$ & $\begin{array}{l}\text { Histologic } \\
\text { examination and } \\
\text { temperature } \\
\text { measurement. }\end{array}$ & Cryosurgery & $\begin{array}{l}\text { No pathologic fractures } \\
\text { were observed in rabbit } \\
\text { tibiae. The gap in terms } \\
\text { of periosteal bone } \\
\text { apposition between } \\
\text { human and animal } \\
\text { bones was the likely } \\
\text { cause of this difference. } \\
\text { Rabbit bone, then, is not } \\
\text { a suitable model to study } \\
\text { this kind of } \\
\text { biomechanical } \\
\text { dynamics. }\end{array}$ \\
\hline $\begin{array}{l}\text { Bachus et al., } \\
2000 \text { [85] }\end{array}$ & $\begin{array}{l}\text { Human } \\
\text { femur }\end{array}$ & Ex vivo & Thermocouple & $\begin{array}{c}\text { Standard } \\
\text { surgical drilling }\end{array}$ & $\begin{array}{l}\text { Higher load reduces the } \\
\text { risk of thermal necrosis. }\end{array}$ \\
\hline $\begin{array}{l}\text { Vercellotti et al., } \\
2005 \text { [86] }\end{array}$ & $\begin{array}{l}\text { Dog } \\
\text { alveolar bone }\end{array}$ & $\begin{array}{c}\text { In vivo } \\
\text { The animals were } \\
\text { sacrificed } \\
\text { immediately after the } \\
\text { surgical procedure } \\
\text { and at } 14,28 \text { and } 56 \\
\text { days postoperatively. } \\
\text { Some bone } \\
\text { specimens were } \\
\text { collected } \\
\text { immediately after the } \\
\text { surgery as well. }\end{array}$ & $\begin{array}{l}\text { Histomorphometric } \\
\text { analysis }\end{array}$ & $\begin{array}{l}\text { Piezosurgery } \\
\text { Mectron Dental } \\
\text { Technology, } \\
\text { carbide bur and } \\
\text { diamond bur }\end{array}$ & $\begin{array}{l}\text { By day } 56, \text { the surgical } \\
\text { sites treated by burs } \\
\text { evidenced a loss of bone, } \\
\text { versus a bone gain in the } \\
\text { piezo-treated sites. }\end{array}$ \\
\hline
\end{tabular}


Table 4. Cont.

\begin{tabular}{|c|c|c|c|c|c|}
\hline Author & $\begin{array}{c}\text { Animal } \\
\text { Model }\end{array}$ & Type of Study & $\begin{array}{l}\text { Material and } \\
\text { Methods }\end{array}$ & Osteotomy Device & Conclusions \\
\hline $\begin{array}{c}\text { Preti et al., } \\
2007 \text { [87] }\end{array}$ & Mini pig tibia & $\begin{array}{c}\text { In vivo } \\
\text { The animals were } \\
\text { sacrificed at } 7,14,28 \\
\text { and } 56 \text { days } \\
\text { postoperatively. } \\
\text { Some tibial bone } \\
\text { specimens were } \\
\text { collected } \\
\text { immediately after the } \\
\text { surgery as well. }\end{array}$ & $\begin{array}{l}\text { Histomorphology } \\
\text { and levels of } \\
\text { bone } \\
\text { morphogenetic } \\
\text { protein (BMP)-4, } \\
\text { transforming } \\
\text { growth factor } \\
\text { (TGF)- } \beta 2 \text {, tumor } \\
\text { necrosis } \\
\text { factor-alpha, and } \\
\text { interleukin-1 } \beta \\
\text { and -10 were } \\
\text { evaluated in the } \\
\text { peri-implant } \\
\text { osseous samples. }\end{array}$ & $\begin{array}{c}\text { Piezosurgery } \\
\text { Mectron Dental } \\
\text { Technology and } \\
\text { drilling according to } \\
\text { Branemark protocol }\end{array}$ & $\begin{array}{l}\text { Piezoelectric bone } \\
\text { surgery appears to be } \\
\text { more efficient in the first } \\
\text { phases of bone healing; it } \\
\text { induced an earlier } \\
\text { increase in BMPs, } \\
\text { controlled the } \\
\text { inflammatory process } \\
\text { better and stimulated } \\
\text { bone remodeling as early } \\
\text { as } 56 \text { days } \\
\text { post-treatment. }\end{array}$ \\
\hline $\begin{array}{c}\text { Maurer et al., } \\
2008 \text { [88] }\end{array}$ & Rabbit skull & Ex vivo & $\begin{array}{l}\text { Light microscopy, } \\
\text { environmental } \\
\text { surface electron } \\
\text { microscopy } \\
\text { (ESEM) and } \\
\text { confocal laser } \\
\text { scanning } \\
\text { microscopy } \\
\text { (CLSM). }\end{array}$ & $\begin{array}{l}\text { Rotating instrument, } \\
\text { micro-saw, } \\
\text { Piezosurgery-Mectron } \\
\text { Dental Technology }\end{array}$ & $\begin{array}{l}\text { Bony structure integrity } \\
\text { observed after the } \\
\text { ultrasonic technique. }\end{array}$ \\
\hline $\begin{array}{l}\text { Queiroz et al., } \\
2008 \text { [89] }\end{array}$ & Rabbit tibia & $\begin{array}{l}\text { In vivo } \\
\text { The animals were } \\
\text { sacrificed } \\
\text { immediately after the } \\
\text { surgical procedure. }\end{array}$ & $\begin{array}{l}\text { Immunoistoc } \\
\text { hemistry, } \\
\text { scanning electron } \\
\text { microscopy }\end{array}$ & $\begin{array}{l}\text { Conventional } \\
\text { drilling }\end{array}$ & $\begin{array}{l}\text { It is preferable to use a } \\
\text { less traumatic surgical } \\
\text { protocol in order to } \\
\text { preserve cell viability. } \\
\text { After the thirtieth } \\
\text { perforation, it is possible } \\
\text { to observe a protein } \\
\text { balance alteration. }\end{array}$ \\
\hline \multirow{2}{*}{$\begin{array}{l}\text { Bertollo et al., } \\
2010 \text { [16] }\end{array}$} & Pig femur & Ex vivo & $\begin{array}{l}\text { Infrared Thermal } \\
\text { Imaging Camera } \\
\text { (Digicam-IR, } \\
\text { Ircon, Niles, IL, } \\
\text { USA) }\end{array}$ & $\begin{array}{l}\text { Pneumatic surgical } \\
\text { handpiece, 2- and } \\
\text { 3-fluted drills-7100 } \\
\text { Drill MicroAire } \\
\text { Surgical Instruments } \\
\text { LLC, Charlottesville, } \\
\text { VA, USA }\end{array}$ & \multirow{2}{*}{$\begin{array}{l}\text { The 3-fluted drills did } \\
\text { not grant a clear } \\
\text { advantage compared to } \\
\text { 2-fluted drills in terms of } \\
\text { better bone healing and } \\
\text { screw fixation and of } \\
\text { reduction of heat rise. }\end{array}$} \\
\hline & Wether tibia & $\begin{array}{c}\text { In vivo } \\
\text { The animals were } \\
\text { sacrificed } 2 \text { and } 4 \\
\text { weeks after the } \\
\text { surgical procedure. }\end{array}$ & $\begin{array}{l}\text { Light } \\
\text { microscopy- } \\
\text { Olympus, Tokyo, } \\
\text { Japan }\end{array}$ & $\begin{array}{l}\text { Said surgical } \\
\text { handpiece mounted } \\
\text { in a sterilizable } \\
\text { mobile drill-press. }\end{array}$ & \\
\hline $\begin{array}{l}\text { Rashad et al., } \\
2011 \text { [90] }\end{array}$ & Bovine rib & Ex vivo & Thermocouples & $\begin{array}{c}\text { A conventional } \\
\text { implant drill system } \\
\text { (Straumann, } \\
\text { Freiburg, Germany) } \\
\text { and two ultrasonic } \\
\text { osteotomic devices: } \\
\text { Piezosurgery } \\
\text { (Mectron Medical } \\
\text { Technology) and } \\
\text { Variosurg (NSK, } \\
\text { Tochigi, Japan). }\end{array}$ & $\begin{array}{l}\text { Implant site preparation } \\
\text { with ultrasonic devices } \\
\text { with adequate irrigation } \\
\text { can provide an equally } \\
\text { safe method compared } \\
\text { to conventional drilling. }\end{array}$ \\
\hline
\end{tabular}


Table 4. Cont.

\begin{tabular}{|c|c|c|c|c|c|}
\hline Author & $\begin{array}{c}\text { Animal } \\
\text { Model }\end{array}$ & Type of Study & Material and Methods & Osteotomy Device & Conclusions \\
\hline $\begin{array}{l}\text { Augustin et al., } \\
\quad 2012 \text { [91] }\end{array}$ & Pig femur & Ex vivo & Thermocouple & $\begin{array}{l}\text { Combination of } \\
\text { internally cooled drill } \\
\text { and a two-step drill. }\end{array}$ & $\begin{array}{l}\text { Internally cooled drill } \\
\text { causes the lower } \\
\text { temperature bone rise. }\end{array}$ \\
\hline $\begin{array}{l}\text { Heinemann et al., } \\
2012 \text { [92] }\end{array}$ & Pig jaw & Ex vivo & Light microscope. & $\begin{array}{l}\text { Piezosurgery-Mectron } \\
\text { Medical Technology, } \\
\text { SONICflex and the } \\
\text { conventional bur } \\
\text { method. }\end{array}$ & $\begin{array}{l}\text { The bone matrix } \\
\text { adjacent to the defect } \\
\text { radius showed intact } \\
\text { osteocytes. }\end{array}$ \\
\hline $\begin{array}{l}\text { Hollstein et. al, } \\
2012 \text { [93] }\end{array}$ & Rabbit skull & Ex vivo & $\begin{array}{l}\text { Light microscopy, } \\
\text { (ESEM), and confocal } \\
\text { laser scanning, } \\
\text { microscopy (CLSM). }\end{array}$ & $\begin{array}{l}\text { Piezosurgery 3, Piezon } \\
\text { Master Surgery, } \\
\text { Piezosurgery-Mectron } \\
\text { Medical Technology, } \\
\text { VarioSurg, } \\
\text { Piezotome } 2\end{array}$ & $\begin{array}{l}\text { The osseous } \\
\text { micro-structure is } \\
\text { preserved. Five different } \\
\text { piezosurgical devices } \\
\text { were evaluated. }\end{array}$ \\
\hline $\begin{array}{l}\text { Schutz et al., } \\
2012 \text { [94] }\end{array}$ & Pig jaw & Ex vivo & $\begin{array}{l}\text { Temperature sensors } \\
\text { and digital volume } \\
\text { tomography images. }\end{array}$ & $\begin{array}{c}\text { Piezosurgery } \\
\text { 3-Mectron Medical } \\
\text { Technology }\end{array}$ & $\begin{array}{l}\text { The correct use of the } \\
\text { ultrasonic device } \\
\text { allowed a safe } \\
\text { osteotomy, not causing } \\
\text { irreversible thermal } \\
\text { damage in the bone. }\end{array}$ \\
\hline $\begin{array}{l}\text { Claire et al., } \\
2013 \text { [95] }\end{array}$ & Pig femur & Ex vivo & $\begin{array}{l}\text { Scanning laser } \\
\text { vibrometer, laser } \\
\text { profilometer, scanning } \\
\text { electron microscope }\end{array}$ & $\begin{array}{c}\text { Piezosurgery } 3 \text { with an } \\
\text { OP3 style insert } \\
\text { tip-Mectron Medical } \\
\text { Technology }\end{array}$ & $\begin{array}{l}\text { In the cortical mode, the } \\
\text { optimal load was of } 150 \\
\text { g. The structure of the } \\
\text { bone has to be taken into } \\
\text { consideration as well. }\end{array}$ \\
\hline $\begin{array}{l}\text { Esteves et al., } \\
2013 \text { [96] }\end{array}$ & Rat tibia & $\begin{array}{c}\text { In vivo } \\
\text { The animals were } \\
\text { sacrificed at } 3,7 \text {, } \\
14,30 \text { and } 60 \\
\text { days } \\
\text { postoperatively. }\end{array}$ & $\begin{array}{l}\text { Histomorphometric } \\
\text { analysis, } \\
\text { immunohistochemical } \\
\text { staining, RT-PCR } \\
\text { (reverse } \\
\text { transcriptase-polymerase } \\
\text { chain reaction). }\end{array}$ & $\begin{array}{l}\text { Piezo Master Surgery } \\
\text { and conventional } \\
\text { drilling with a } 2 \mathrm{~mm} \\
\text { round diamond coated } \\
\text { tip. }\end{array}$ & $\begin{array}{l}\text { Bone healing dynamics } \\
\text { after piezosurgery are } \\
\text { comparable to those } \\
\text { observed with } \\
\text { conventional drilling. }\end{array}$ \\
\hline $\begin{array}{l}\text { Gulnahar et al., } \\
2013 \text { [56] }\end{array}$ & $\begin{array}{l}\text { Human } \\
\text { mandible }\end{array}$ & $\begin{array}{c}\text { In vivo } \\
\text { Bone specimens } \\
\text { were collected } \\
\text { immediately } \\
\text { following the } \\
\text { surgical } \\
\text { procedure }\end{array}$ & $\begin{array}{l}\text { Heat shock protein } 70 \\
\text { (Hsp70) expression. }\end{array}$ & $\begin{array}{l}\text { Conventional bur and } \\
\text { piezosurgery. }\end{array}$ & $\begin{array}{l}\text { Conventional burs } \\
\text { determined more } \\
\text { aggressive procedures, } \\
\text { showing significantly } \\
\text { higher Hsp70 expression } \\
\text { in consequence of the } \\
\text { higher stress induced. }\end{array}$ \\
\hline $\begin{array}{l}\text { Ma et al., } \\
2013 \text { [97] }\end{array}$ & Rabbit skull & $\begin{array}{l}\text { In vivo } \\
\text { The animals were } \\
\text { sacrificed at } 1,2 \text {, } \\
3 \text {, and } 5 \text { weeks } \\
\text { postoperatively. }\end{array}$ & $\begin{array}{l}\text { Light microscopy, } \\
\text { histomorphometric } \\
\text { analysis. }\end{array}$ & $\begin{array}{l}\text { Piezosurgery-Mectron } \\
\text { Medical Technology, } \\
\text { two types of oscillating } \\
\text { steel saw blade. }\end{array}$ & $\begin{array}{l}\text { Advanced bone healing } \\
\text { compared to a } \\
\text { traditional saw was } \\
\text { observed. }\end{array}$ \\
\hline $\begin{array}{l}\text { Bullon et al., } \\
2014 \text { [98] }\end{array}$ & Bovine rib & Ex vivo & Thermocouple & $\begin{array}{l}\text { Drilling with } \\
\text { precipitation-hardening } \\
\text { stainless steel (K drills) } \\
\text { or with martensitic } \\
\text { stainless steel (S drills). }\end{array}$ & $\begin{array}{c}\text { Irrigation had a } \\
\text { significant impact on } \\
\text { heat generation, while } \\
\text { drill use and type did } \\
\text { not. }\end{array}$ \\
\hline
\end{tabular}


Table 4. Cont.

\begin{tabular}{|c|c|c|c|c|c|}
\hline Author & $\begin{array}{l}\text { Animal } \\
\text { Model }\end{array}$ & Type of Study & $\begin{array}{l}\text { Material and } \\
\text { Methods }\end{array}$ & Osteotomy Device & Conclusions \\
\hline $\begin{array}{l}\text { Lamazza et al., } \\
2014 \text { [99] }\end{array}$ & Bovine rib & Ex vivo & $\begin{array}{l}\text { Load cell and } \\
\text { fluoroptic } \\
\text { thermometer. }\end{array}$ & $\begin{array}{l}\text { Piezosurgery with } \\
\text { different tips (IM1s, } \\
\text { IM2s, P2-3, } \\
\text { IM3)-Mectron } \\
\text { Medical Technology }\end{array}$ & $\begin{array}{l}\text { Load, movements } \\
\text { management and bone } \\
\text { features play critical } \\
\text { roles in temperature rise. } \\
\text { Irrigation fluid } \\
\text { temperature and the } \\
\text { clogging effect also } \\
\text { contribute to this } \\
\text { phenomenon. }\end{array}$ \\
\hline $\begin{array}{l}\text { Stelzle et al., } \\
2014 \text { [100] }\end{array}$ & Pig skull & Ex vivo & $\begin{array}{l}\text { Thermocouple, } \\
\text { histomorphometric } \\
\text { analysis. }\end{array}$ & $\begin{array}{l}\text { Piezosurgery-Mectron } \\
\text { Medical Technology, } \\
\text { spiral burs and } \\
\text { trephine burs }\end{array}$ & $\begin{array}{l}\text { Piezosurgery generates } \\
\text { more bone damage and } \\
\text { higher temperatures } \\
\text { than conventional } \\
\text { drilling devices when } \\
\text { used on high load levels. } \\
\text { The maximum load } \\
\text { should be } 400 \mathrm{~g} \text {. }\end{array}$ \\
\hline $\begin{array}{l}\text { Stoetzer et al., } \\
2014 \text { [72] }\end{array}$ & Rat calvaria & $\begin{array}{c}\text { In vivo } \\
\text { The animals were not } \\
\text { sacrificed. } \\
\text { The evaluations were } \\
\text { performed } \\
\text { immediately after the } \\
\text { surgery and } 3 \text { and } 8 \\
\text { days postoperatively. }\end{array}$ & $\begin{array}{l}\text { Intravital } \\
\text { microscopy of } \\
\text { microcirculatory } \\
\text { parameters. }\end{array}$ & $\begin{array}{l}\text { Periosteal elevator and } \\
\text { piezoelectric device. }\end{array}$ & $\begin{array}{l}\text { A better periosteal } \\
\text { microcirculation was } \\
\text { found in piezoelectric } \\
\text { device osteotomies. }\end{array}$ \\
\hline $\begin{array}{l}\text { Yang et al., } \\
2014 \text { [101] }\end{array}$ & Mice skull & $\begin{array}{l}\text { In vivo } \\
\text { The animals were not } \\
\text { sacrificed. } \\
\text { The evaluations were } \\
\text { performed the day } \\
\text { following the surgery } \\
\text { and } 2,4 \text { and } 8 \text { weeks } \\
\text { postoperatively. }\end{array}$ & $\begin{array}{c}\text { Micro-CT } \\
\text { (micro-computed } \\
\text { tomography). }\end{array}$ & $\begin{array}{l}\text { Surgystar diamond } \\
\text { round tip and } \\
\text { Piezoelectric System } \\
\text { (Synthes), }\end{array}$ & $\begin{array}{l}\text { Piezosurgery provided } \\
\text { faster bone healing in } \\
\text { comparison with } \\
\text { mechanical } \\
\text { instrumentation. }\end{array}$ \\
\hline $\begin{array}{l}\text { Rashad et al., } \\
2015 \text { [102] }\end{array}$ & Bovine rib & Ex vivo & Thermocouple. & $\begin{array}{l}\text { Conventional, sonic } \\
\text { and ultrasonic } \\
\text { osteotomic devices. }\end{array}$ & $\begin{array}{l}\text { Sonic and ultrasonic } \\
\text { devices provided the } \\
\text { safer osteotomies in } \\
\text { terms of heat generation. } \\
\text { Irrigation was crucial to } \\
\text { prevent temperature rise. }\end{array}$ \\
\hline $\begin{array}{l}\text { Tekdal et al., } \\
2015 \text { [55] }\end{array}$ & $\begin{array}{l}\text { Human } \\
\text { maxilla }\end{array}$ & $\begin{array}{c}\text { In vivo } \\
\text { The evaluations were } \\
\text { performed until } 24 \\
\text { weeks } \\
\text { postoperatively, with } \\
\text { a different timetable } \\
\text { for each parameter } \\
\text { considered. }\end{array}$ & $\begin{array}{l}\text { Peri-implant } \\
\text { sulcular fluid } \\
\text { (PISF) analysis, } \\
\text { periapical } \\
\text { radiographs and } \\
\text { cone beam } \\
\text { computed } \\
\text { tomography } \\
\text { (CBCT). }\end{array}$ & $\begin{array}{l}\text { Piezosurgery and } \\
\text { conventional drilling. }\end{array}$ & $\begin{array}{c}\text { On the biochemical side, } \\
\text { piezosurgery provided a } \\
\text { reduced inflammatory } \\
\text { response of the bone, } \\
\text { while on the } \\
\text { radiographic analysis, } \\
\text { conventional drilling } \\
\text { and piezosurgery had } \\
\text { similar crestal bone loss } \\
\text { values. }\end{array}$ \\
\hline $\begin{array}{l}\text { Boa et al., } \\
2016 \text { [103] }\end{array}$ & Bovine rib & Ex vivo & $\begin{array}{c}\text { Temperature } \\
\text { measurement } \\
\text { cavities. }\end{array}$ & $\begin{array}{l}\text { Freehand drilling and } \\
\text { surgical-guided } \\
\text { drilling, combined } \\
\text { with irrigation fluids at } \\
\text { different temperatures. }\end{array}$ & $\begin{array}{l}\text { Drilling through a } \\
\text { surgical guide allowed } \\
\text { the best results, } \\
\text { especially in } \\
\text { combination with the } \\
\text { use of } 10^{\circ} \mathrm{C} \text { pre-cooled } \\
\text { irrigation fluid. }\end{array}$ \\
\hline
\end{tabular}


Table 4. Cont.

\begin{tabular}{|c|c|c|c|c|c|}
\hline Author & $\begin{array}{l}\text { Animal } \\
\text { Model }\end{array}$ & Type of Study & $\begin{array}{l}\text { Material and } \\
\text { Methods }\end{array}$ & Osteotomy Device & Conclusions \\
\hline $\begin{array}{l}\text { Gabric et al., } \\
2016 \text { [104] }\end{array}$ & Rat tibia & $\begin{array}{c}\text { In vivo } \\
\text { The animals were } \\
\text { sacrificed } \\
\text { immediately after the } \\
\text { surgical procedure } \\
\text { and at } 1,2 \text { and } 3 \\
\text { weeks } \\
\text { postoperatively. }\end{array}$ & $\begin{array}{l}\text { 3D laser scanning } \\
\text { technique (i.e., laser } \\
\text { triangulation } \\
\text { profilometry). }\end{array}$ & $\begin{array}{l}\text { Piezosurgery-Mectron } \\
\text { Medical Technology, } \\
\text { Er:YAG laser both in } \\
\text { contact mode and } \\
\text { non-contact mode. }\end{array}$ & $\begin{array}{l}\text { Osteotomies executed } \\
\text { with Er:YAG laser in } \\
\text { non-contact mode were } \\
\text { the fastest to heal. }\end{array}$ \\
\hline $\begin{array}{l}\text { Lamazza et al., } \\
2016[105]\end{array}$ & $\begin{array}{c}\text { Bovine } \\
\text { rib and } \\
\text { femur }\end{array}$ & Ex vivo & $\begin{array}{l}\text { Fiber optic } \\
\text { thermometer. }\end{array}$ & $\begin{array}{l}\text { Diamond tip-IM1s, } \\
\text { Mectron Medical } \\
\text { Technology. }\end{array}$ & $\begin{array}{l}\text { Cortico-cancellous bone } \\
\text { samples presented more } \\
\text { variability in } \\
\text { temperature values } \\
\text { compared to cortical } \\
\text { bone samples. }\end{array}$ \\
\hline $\begin{array}{l}\text { Szalma et al., } \\
2017 \text { [107] }\end{array}$ & $\begin{array}{l}\text { Pig } \\
\text { mandible }\end{array}$ & Ex vivo & $\begin{array}{c}\text { Thermocouple and } \\
\text { infrared } \\
\text { thermometer. }\end{array}$ & $\begin{array}{c}\text { Diamond drills, } \\
\text { tungsten carbide drills, } \\
\text { piezoelectric diamond } \\
\text { sphere and saw. }\end{array}$ & $\begin{array}{l}\text { The use of irrigation } \\
\text { fluid at } 7^{\circ} \mathrm{C} \text { and } \\
\text { pre-drilling is crucial to } \\
\text { avoid a potentially } \\
\text { nerve-damaging } \\
\text { temperature rise in } \\
\text { piezosurgical } \\
\text { osteotomies. The speed } \\
\text { of piezosurgery and of } \\
\text { the other devices is } \\
\text { similar. }\end{array}$ \\
\hline $\begin{array}{l}\text { Anesi et al., } \\
2018 \text { [8] }\end{array}$ & $\begin{array}{c}\text { Rabbit } \\
\text { skull }\end{array}$ & $\begin{array}{l}\text { In vivo } \\
\text { The animals were } \\
\text { sacrificed } 15 \text { days } \\
\text { following the } \\
\text { surgical procedure. }\end{array}$ & $\begin{array}{c}\text { Histology and } \\
\text { enzymatic assay } \\
\text { Histomorphometry. } \\
\text { Scanning and } \\
\text { transmission electron } \\
\text { microscope. } \\
\text { Nano-mechanical } \\
\text { analysis }\end{array}$ & $\begin{array}{c}\text { Piezosurgery Medical } \\
\text { Piezosurgery Plus }^{\circledR}, \\
\text { Mectron Medical } \\
\text { Technology. } \\
\text { Physiodispenser 7000, } \\
\text { Nouvag AG. }\end{array}$ & $\begin{array}{l}\text { Piezosurgical group } \\
\text { shows more advanced } \\
\text { stages of bone healing } \\
\text { compared to } \\
\text { conventional bur. }\end{array}$ \\
\hline $\begin{array}{l}\text { Favero et al., } \\
2018 \text { [108] }\end{array}$ & $\begin{array}{l}\text { Sheep } \\
\text { tibia }\end{array}$ & $\begin{array}{c}\text { In vivo } \\
\text { The animals were } \\
\text { sacrificed at } 1,2 \text { and } \\
6 \text { weeks } \\
\text { postoperatively. }\end{array}$ & $\begin{array}{c}\text { Eclipse Ci } \\
\text { microscope (Nikon } \\
\text { Corporation, Japan) } \\
\text { with a digital video } \\
\text { camera (Digital Sight } \\
\text { DS-2Mv, Nikon } \\
\text { Corporation, Japan). }\end{array}$ & $\begin{array}{l}\text { Conventional drilling, } \\
\text { both at high and mixed } \\
\text { speed }\end{array}$ & $\begin{array}{l}\text { There was no difference } \\
\text { between the two groups. }\end{array}$ \\
\hline $\begin{array}{l}\text { Junior et al., } \\
2018 \text { [109] }\end{array}$ & $\begin{array}{l}\text { Bovine } \\
\text { femur }\end{array}$ & Ex vivo & $\begin{array}{l}\text { T-type } \\
\text { thermo-couple and } \\
\text { Scanning Electron } \\
\text { Microscope (SEM) }\end{array}$ & $\begin{array}{l}\text { Piezoelectric tips } \\
\text { (Driller) and } \\
\text { tri-helicoid dental burs } \\
\text { (Dentoflex) }\end{array}$ & $\begin{array}{l}\text { The use of either rotatory } \\
\text { burs or piezoelectric tips } \\
\text { generates a temperature } \\
\text { that does not affect the } \\
\text { tissue healing. Burs } \\
\text { create a smooth surface, } \\
\text { and piezoelectric tips } \\
\text { show a rougher and } \\
\text { condensed bone surface. } \\
\text { The wear of both } \\
\text { systems does not cause a } \\
\text { relevant increase in } \\
\text { temperature after the } \\
\text { preparation of } 30 \\
\text { surgical beds. }\end{array}$ \\
\hline
\end{tabular}


Table 4. Cont.

\begin{tabular}{|c|c|c|c|c|c|}
\hline Author & $\begin{array}{c}\text { Animal } \\
\text { Model }\end{array}$ & Type of Study & $\begin{array}{l}\text { Material and } \\
\text { Methods }\end{array}$ & $\begin{array}{l}\text { Osteotomy } \\
\text { Device }\end{array}$ & Conclusions \\
\hline $\begin{array}{l}\text { Lajolo et al., } \\
2018 \text { [110] }\end{array}$ & Porcine rib & Ex vivo & $\begin{array}{c}\text { Implant site } \\
\text { preparation with } \\
\text { conventional drill } \\
\text { system vs. } \\
\text { piezoelectric system. } \\
\text { Infrared } \\
\text { thermometer was } \\
\text { positioned } \\
\text { underneath }\end{array}$ & $\begin{array}{c}\text { Premium } \\
\text { Surgical Kit } \\
\text { Kohno, Sweden } \\
\text { \& Martina s.p.a. } \\
\text { OP4 insert. } \\
\text { Piezosurgery- } \\
\text { Mectron Medical } \\
\text { Technology }\end{array}$ & $\begin{array}{l}\text { "Bone overheating using a } \\
\text { piezosurgery unit is a } \\
\text { potential risk during } \\
\text { implant site preparation". }\end{array}$ \\
\hline $\begin{array}{l}\text { argued by } \\
\text { Stacchi et al., } \\
2018[111]\end{array}$ & \multicolumn{5}{|c|}{$\begin{array}{l}\text { Methodological flaws were revealed: OP4 insert is not suitable for implant suite preparation according to } \\
\text { manufacturer's booklet. Excessive pressure load applied on the piezosurgical tip during implant site } \\
\text { preparation. No correct movement of the piezosurgical handpiece was applied in the study. }\end{array}$} \\
\hline $\begin{array}{l}\text { Singh et al., } \\
2018 \text { [15] }\end{array}$ & $\begin{array}{l}\text { Bovine } \\
\text { bone }\end{array}$ & Ex vivo & Optical microscope & $\begin{array}{l}\text { Vibrational bone } \\
\text { drilling }\end{array}$ & $\begin{array}{l}\text { Rotational speed is the } \\
\text { major responsibility of } \\
\text { heat generation, although } \\
\text { all parameters considered } \\
\text { affect the result. The best } \\
\text { results were obtained with } \\
\text { a mid-range rotational } \\
\text { speed. }\end{array}$ \\
\hline $\begin{array}{l}\text { Stocchero et } \\
\text { al., } 2018 \text { [112] }\end{array}$ & $\begin{array}{l}\text { Sheep } \\
\text { mandible }\end{array}$ & $\begin{array}{c}\text { In vivo } \\
\text { The animals were } \\
\text { sacrificed at } 5 \text { and } 10 \\
\text { weeks } \\
\text { postoperatively. }\end{array}$ & $\begin{array}{c}\text { Histomorphometric, } \\
\mu-C T \text { and } \\
\text { biomechanical } \\
\text { analysis }\end{array}$ & $\begin{array}{l}\text { Two different } \\
\text { drilling protocols }\end{array}$ & $\begin{array}{l}\text { In the long term, no } \\
\text { difference was observed } \\
\text { between the two groups, } \\
\text { although in the early } \\
\text { period, there was greater } \\
\text { cortical bone remodeling } \\
\text { in the undersized } \\
\text { preparation group. }\end{array}$ \\
\hline $\begin{array}{l}\text { Tepedino et } \\
\text { al., } 2018 \text { [113] }\end{array}$ & $\begin{array}{l}\text { Bovine } \\
\text { bone }\end{array}$ & Ex vivo & $\begin{array}{l}\text { Thermo-control laser, } \\
\text { Scanning Electron } \\
\text { Microscopy (SEM) } \\
\text { and light microscope }\end{array}$ & $\begin{array}{c}\text { Conventional } \\
\text { rotating bur and } \\
\text { Piezosurgery } 3 \\
\text { with an OP5 } \\
\text { insert-Mectron } \\
\text { Medical } \\
\text { Technology }\end{array}$ & $\begin{array}{l}\text { Piezosurgery caused lower } \\
\text { bone damage and } \\
\text { temperature rise than the } \\
\text { conventional rotating bur. }\end{array}$ \\
\hline $\begin{array}{l}\text { Zheng et al., } \\
2018 \text { [114] }\end{array}$ & Pig femur & Ex vivo & Infrared camera & $\begin{array}{l}\text { Ultrasonically } \\
\text { assisted drilling, } \\
\text { conventional } \\
\text { drilling }\end{array}$ & $\begin{array}{l}\text { Ultrasonically assisted } \\
\text { drilling provided less bone } \\
\text { damage and generated } \\
\text { lower temperatures. }\end{array}$ \\
\hline $\begin{array}{l}\text { Alam et al., } \\
2019 \text { [115] }\end{array}$ & $\begin{array}{l}\text { Bovine } \\
\text { femur }\end{array}$ & Ex vivo & $\begin{array}{l}\text { Thermocouples, } \\
\text { two-component } \\
\text { dynamometer (Type } \\
\text { 9271A, Kistler), } \\
\text { system microscope } \\
\text { (BX53, Olympus), } \\
\text { digital microscope } \\
\text { (DP22, Olympus) }\end{array}$ & $\begin{array}{l}\text { Vibrational } \\
\text { drilling-Orthofix, } \\
\text { Italy }\end{array}$ & $\begin{array}{l}\text { The best results were } \\
\text { obtained by setting a } \\
\text { lower drilling speed, a } \\
\text { lower feed rate and a } \\
\text { frequency of } 20 \mathrm{kHz} \text {. }\end{array}$ \\
\hline $\begin{array}{l}\text { Pavone et al., } \\
2019 \text { [116] }\end{array}$ & Rat calvaria & $\begin{array}{c}\text { In vivo } \\
\text { The animals were } \\
\text { sacrificed } \\
\text { immediately after the } \\
\text { surgical procedure } \\
\text { and at } 7,15,30 \text { and } \\
60 \text { days } \\
\text { postoperatively. }\end{array}$ & $\begin{array}{c}\text { Histometric and } \\
\text { histological analysis }\end{array}$ & $\begin{array}{l}\text { Er,Cr:YSGG laser, } \\
\text { trephine drill }\end{array}$ & $\begin{array}{l}\text { The Er,Cr:YSSG laser } \\
\text { osteotomy allowed the } \\
\text { best healing in animals } \\
\text { exposed to cigarette } \\
\text { smoke. }\end{array}$ \\
\hline $\begin{array}{c}\text { Zhang et al., } \\
2019 \text { [117] }\end{array}$ & $\begin{array}{l}\text { Tibetan pig } \\
\text { femur and } \\
\text { radius }\end{array}$ & In vivo & Light microscope & $\begin{array}{l}\text { Drilling in five } \\
\text { different bits } \\
\text { geometries }\end{array}$ & $\begin{array}{l}\text { Chisel edge, drill bit } \\
\text { geometry, flute number, } \\
\text { edges, steps and direction } \\
\text { affect bone damage level } \\
\text { and its characteristics. }\end{array}$ \\
\hline $\begin{array}{l}\text { Crovace et al., } \\
2020[118]\end{array}$ & $\begin{array}{l}\text { Dogs and } \\
\text { cats; } \\
\text { calvaria or } \\
\text { spine }\end{array}$ & $\begin{array}{l}\text { In vivo. } \\
\text { Ostetotomic bone } \\
\text { immediate sampling; } \\
\text { the animals were not } \\
\text { sacrificed. }\end{array}$ & $\begin{array}{l}\text { X-ray or CT scan. } \\
\text { Histology }\end{array}$ & $\begin{array}{c}\text { Piezosurgery, } \\
\text { Mectron Medical } \\
\text { Technology }\end{array}$ & $\begin{array}{l}\text { No signs of bone } \\
\text { overheating. }\end{array}$ \\
\hline
\end{tabular}


Most of the studies investigated the effects of the heat generated by the metal-bone interface during drilling: indeed, the resulting friction can cause thermal osteonecrosis. Thermal damaged bone is of great clinical relevance because it is not capable of holding the implants and screws for a long time [15].

Well documented experimental osteotomic studies were conducted in the late 1950s, when Thompson [119] reported the "index of viability", i.e., a parameter for evaluating the distance between the first normal osteocyte and the edge of the osteotomy; it indicated the drill's cutting effects upon the cellular elements of the bone. This index can be carried out on ex vivo and in vivo samples and this author well distinguished for the first time between ex vivo and in vivo studies on animals [119]. A zone of aseptic thermal necrosis was described by Thompson in 1958 [119], which was characterized by the degeneration of the osteocytes (pyknosis of the nuclei, complete disintegration of the cells, osteocyte lacunae devoid of cellular elements). Decreased bone damage is indicated by a low viability index value and larger bone damage by the higher values.

In the mid-1960s, it was demonstrated that increased bur cutting speed with a cooling agent does not cause increased bone damage, i.e., decreased bone damage occurred if increased speed was applied [78]. Ultraspeed or increased speed was also supported by in vivo findings of Spatz [79], in terms of lesser inflammatory response and faster bone recovery.

A rudimentary ultrasonic device was verified in the 1970s, found to be related to slower bone healing compared to rotational bur [80]. Ultrasonic and piezoelectric osteotomy was developed and rediscovered in the early 2000s; on the contrary, bone healing outcome proved to be faster with piezosurgical devices with respect to a traditional rotational bur [8].

In 1983, Eriksson et al. investigated the friction and the heat generated from the metal-bone interface during drilling: it was eventually established that the lowest temperature threshold for thermal osteonecrosis is $47^{\circ} \mathrm{C}$ for one minute. This study was particularly informative because it was conducted in an in vivo animal model (rabbit) and represents nowadays a pillar of the relevant literature [120].

Conflicting conclusions in terms of the effect of temperature in bone tissue can be seen by comparing in vivo and in vitro studies, as Wächter et al. [82] concluded in their study. The scholar revealed lower bone temperature in in vivo samples: bleeding flow could evacuate more thermal energy with respect to ex vivo settings [82].

Post-osteotomy callus formation and bone healing are influenced by the biological status and potency of the bone at the cut surfaces [121]. Excessive heat and thermal necrosis may irreversibly impair the bone healing process [122]. To limit the temperature increase, both bur and oscillating saws are usually cooled during the cutting process [123].

Thermal damage in the surrounding cortical bone depends not only on the maximum temperature value but also on the duration of temperature elevation and consequently on drilling time. High speed and increased force in drilling cause a small rise in temperature, due to the decrease in the drilling time [83].

Drilling with forces between 57 and $130 \mathrm{~N}$ is related to a minor increase in temperature, and similarly, the time interval in which the temperature remains above $50^{\circ} \mathrm{C}$ is shorter [85]. Moreover, the results from Bachus contradict the work published by Abouzgia et al. [85] which had even shown that the cortical bone temperatures decreased between 1.5 and $9.0 \mathrm{~N}$.

Factors that influence heat generation during bur osteotomy were investigated by several studies and they include speed, drill force, irrigation, drill design and drill diameter. Another widely used technology as a standard tool for osteotomies is the oscillating saw [102].

From Vercellotti's [86] paper to nowadays, most studies have compared the effects on bone of traditional rotatory osteotomes versus ultrasonic (piezosurgical) devices. The research interest in ultrasonic osteotomy is justified by the fact that piezosurgical osteotomy is extremely precise and provides arbitrary cut geometries, prompt handling, efficient bone cutting and minimal damage to adjacent soft tissue structures [102].

Vercellotti et al. [86] applied an in vivo model of dog alveolar ridges, demonstrating an improved bone healing process in the piezosurgically treated group. The index of viability of bone cells after piezosurgery was studied histologically by numerous authors in bone grafting procedures for 
dental purposes $[124,125]$. Histomorphometric and molecular analysis was evaluated together by Preti et al. [87]; the authors established that piezosurgery may accelerate the earlier phases of the dental implant osteointegration when compared with rotational drilling.

Bone surfaces were examined by Maurer [88] with three microscopic techniques (light microscopy, environmental scanning electron microscope-ESEM, confocal laser scanning microscope-CLSM) after using different procedures of osteotomy (reciprocate micro-saw, Lindemann bur, ultrasonic osteotome). ESEM and CLSM entail an appraisal of unmodified bony specimens, being non-destructive examination techniques. In this histological investigation, ultrasonic osteotome activity was not related to osteonecrosis of the trabecular bone. CLSM permits a quantitative evaluation of bone surface roughness [88].

Augustin and co-workers [91] in an ex vivo model studied in depth the thermal damage to bone as a combined result of the temperature and the duration of elevated temperature: the relation of maximum bone temperature and the period of that increased temperature over the critical value was described. Drilling with carbide spiral drills $(2.5-4.5 \mathrm{~mm})$ for dental implantology, the bone temperature persisted around $50{ }^{\circ} \mathrm{C}$ for $50 \mathrm{~s}$ in $95 \%$ of results, not adequate for avoiding thermal osteonecrosis during drilling $\left(\leq 47^{\circ} \mathrm{C}\right.$ for one minute, as demonstrated by Eriksson et al.) [120].

Comparing different ex vivo inserts for piezosurgical osteotome, it was found that cortical bone thickness had surprisingly no influence on intraosseous temperature generation, which remained, however, below the threshold of $47.8^{\circ} \mathrm{C}$ for $1 \mathrm{~min}$, without irreversible thermal damage in the bone [94]. These data were statistically supported and in contrast to the previous study of Eriksson, which was conducted with traditional rotary osteotomes [81]. Considering the investigation methods, these results are difficult to compare. The author concluded that in vivo measurements need to be carried out to confirm the data.

While cortical bone thickness appeared a secondary factor following piezosurgery, the structure of the bone seemed to be an important factor in the cut characteristics: higher cut lengths and widths were present in the spongeous bone compared to the cortical bone [95].

Esteves et al. [96] conducted an in vivo study on rat tibia (histological, histomorphometric, immunohistochemical and molecular analysis); comparative appraisal of bone recovery after osteotomic lines performed by rotating drill or piezosurgery did not demonstrate significant differences between the two animal groups.

An in vivo histomorphometric study by Ma et al. [97] revealed no statistically significant differences in comparing bone healing after osteotomy performed with piezosurgery versus oscillatory saws; increased bone remodeling activity in early phases was observed for the piezoelectric surgery group.

Cortico/cancellous samples (ex vivo) are a simulation of in vivo conditions frequently used by scholars, but they are affected by greater variability of results. In an ex vivo bone model with a piezosurgical device, three main factors were finally identified among the others for having a great influence on the heat production: working load, working movement management and bone features [99]. Rashad et al. in 2015 found that ultrasonic osteotomies cause significantly lower heat compared to rotary bur osteotomies [102]. However, both these scholars concluded that (in vivo) animal studies were essential for understanding how bone healing occurred after ultrasonic osteotomies and how blood flow and biological factors fit together with ex vivo findings [99,102].

In a rotatory bur (drilling bur), it was found by histopathology that the heat generation is mainly dependent on rotational speed: at high rotational speed ( $3000 \mathrm{r} / \mathrm{min})$, there is a severe thermal osteonecrosis [15]. These results contradict previous findings in the 1960s and 1970s, when ultraspeed or high rotational speed were recommended for avoiding thermal osteonecrosis [78-80].

Modulating the irrigation temperature can be an effective strategy in reducing heat during osteotomy with a drilling bur. Studies on endosseous dental implant site demonstrated that the use of precooled irrigation at $10^{\circ} \mathrm{C}$ entails a significant reduction in peak temperature compared with what was achieved when irrigating at room temperature [103].

Bone removal approximating the inferior alveolar nerve canal was investigated through an ex vivo experimental study conducted by Szalma [107]. Compared to a drill, this ex vivo study 
confirmed that piezoelectric bone removal approximating the inferior alveolar canal resulted in higher temperature-increasing effects on the surface of the inferior alveolar nerve [107]. The author eventually suggested combined bone removal (i.e., tungsten carbide pre-drilling completed with piezoelectric tip) with $7{ }^{\circ} \mathrm{C}$ pre-cooled irrigation to limit the intracanal temperature increase [107].

During endosseous dental implant site preparation, bone overheating using a piezosurgery was measured, resulting in two times more with respect to a conventional drill [110].

Augmented bone overheating with piezosurgical devices compared to a bur drill was an unexpected finding. Other authors questioned some of the methods that led to these results, such as Stacchi et al. [111], who discussed the previous ex vivo investigation of Lajolo et al [110]. For example, ultrasonic tip choice in the experiment can lead to abnormal heat generation if the use is improper for the purpose (side-cutting insert instead of dental implant site preparation insert). Stacchi et al. (2018) also described that applied pressure load on the handpiece was excessive for that device and this could induce a higher temperature rise [111]. Pressure load should be chosen according to the specific characteristics of the tip and device (piezosurgical, rotatory, and oscillating or reciprocating saw). Moreover, as in the paper of Lajolo et al [126], the laboratory supported arm for the handpiece should reproduce the movement of the hand in the operative theater (sliding movement is not comparable to rotating movement). Non-overlapping conditions between experimental and clinical setting could lead to distorted interpretation of results from studies conducted in laboratory settings [111].

Previous findings of Lajolo [126] and Szalma [107] about bone overheating with piezosurgical devices were questioned by Zheng [114] in a further ex vivo model. He found that the cortical bone temperature during piezosurgical osteotomy was lower than during rotational drilling. Moreover, according to this study, the impact of the drilling factors on bone temperature was in the order of drill diameter, rotational speed, feed speed and the frequency and amplitude of the piezosurgical vibration [114].

Erbium-doped yttrium aluminum garnet (Er:YAG) laser was applied as osteotome in maxillo-facial surgery in 2007 [10]. A single study in vivo compared a Er:YAG laser with the piezosurgical technique, without histomorphometric evaluation but with bone volume measurement by laser triangulation profilometry [104]; considering the limit of investigation methods, the Er:YAG laser showed faster bone healing with respect to the piezosurgical sample. Pavone et al. (2018) [116] carried out an in vivo study in rats exposed to inhalation of cigarette smoke, comparing a Er,Cr:YSGG laser (erbium, chromium: yttrium, scandium, gallium and garnet) and trephine drilling. The Er,Cr:YSGG-S group revealed higher bone formation with statistical significance compared to the trephine drilling group.

Microcracks are mechanical complications that can be considered a further parameter to evaluate bone damage after the osteotomy procedure and fixation/prosthesis positioning [127,128]. If the gap formed by the microcracks around the prosthesis surface overtakes $50 \mathrm{~mm}$, the capacity of the bone tissue growing into the prosthesis will be decreased [127,128], proving that drill geometries influence the mechanical and thermal damage: a standard surgical drill edge (chisel) seems to augment bone damage.

\section{Future Perspectives}

Several ex vivo studies on animal bone were recently dedicated to heat production during osteotomy with conventional drills and piezoelectric devices, particularly in endosseous dental implant sites. In our opinion, outcomes from ex vivo animal models cannot be transferred to clinical practice, because the static finding of bone damage does not necessarily correlate with the effectiveness of the bone healing process (Table 3). Discussing ex vivo results, scholars should only advance perspectives as regards the in vivo conditions, both on animal models and in surgery, since it is not known whether the described bone damage has consequences for bone healing.

The informativeness of the measured data depends on the time of execution, i.e., in tissue out of living (ex vivo) or in living tissue of an animal (in vivo). In turn, in in vivo experiments, histology can be carried out at different stages: immediately after cutting procedures, during the bone healing process and at the end of bone restoration. 
Micro-mechanics, histology, ultrastructural analysis, molecular biology and biochemistry, both in ex vivo or in vivo, are altogether necessary to elucidate the sophisticated processes leading to bone restoration after the cutting procedure.

Therefore, all the above-mentioned techniques, integrating and completing each other, should contribute to shedding new light on the very complex issue of bone healing after osteotomy.

Author Contributions: Conceptualization, A.A. and M.D.B.; validation, L.C.; writing-original draft preparation, M.D.B., A.P. and R.N.; writing-review and editing, A.A., F.C. and M.F.; visualization, R.S.; supervision, C.P. All authors have read and agreed to the published version of the manuscript.

Funding: This research received no external funding.

Conflicts of Interest: The authors declare no conflict of interest.

\section{References}

1. Luvar, M.; Kanthan, S.R.; Roshan, G.; Saw, A. Pattern of Cortical Fracture following Corticotomy for Distraction Osteogenesis. Malays. Orthop. J. 2015, 9, 35-39.

2. Dabis, J.; Templeton-Ward, O.; Lacey, A.E.; Narayan, B.; Trompeter, A. The history, evolution and basic science of osteotomy techniques. Strateg. Trauma Limb Reconstr. 2017, 12, 169-180.

3. Green, S.A. Basic Ilizarov Techniques. Tech. Orthop. 1990, 5, 41-52.

4. Wardak, M.M.; Wardak, E. Percutaneous gigli saw osteotomy. Oper. Orthop. Traumatol. 2010, 22, 414-420. [CrossRef]

5. Eidelman, M.; Katzman, A.; Zaidman, M.; Keren, Y. Deformity correction using supramalleolar gigli saw osteotomy and Taylor spatial frame: How to perform this osteotomy safely? J. Pediatr. Orthop. Part B 2011, 20, 318-322. [CrossRef]

6. Makhdoom, A.; Kumar, J.; Siddiqui, A.A. Ilizarov External Fixation: Percutaneous Gigli Saw Versus Multiple Drill-hole Osteotomy Techniques for Distraction Osteogenesis. Cureus 2019, 11, e4973. [CrossRef] [PubMed]

7. Eralp, L.; Kocaoğlu, M.; Özkan, K.; Türker, M. A comparison of two osteotomy techniques for tibial lengthening. Arch. Orthop. Trauma Surg. 2004, 124, 298-300. [CrossRef]

8. Anesi, A.; Ferretti, M.; Cavani, F.; Salvatori, R.; Bianchi, M.; Russo, A.; Chiarini, L.; Palumbo, C. Structural and ultrastructural analyses of bone regeneration in rabbit cranial osteotomy: Piezosurgery versus traditional osteotomes. J. Cranio-Maxillofac. Surg. 2018, 46, 107-118. [CrossRef]

9. Landes, C.A.; Stübinger, S.; Rieger, J.; Williger, B.; Ha, T.K.L.; Sader, R. Critical Evaluation of Piezoelectric Osteotomy in Orthognathic Surgery: Operative Technique, Blood Loss, Time Requirement, Nerve and Vessel Integrity. J. Oral Maxillofac. Surg. 2008, 66, 657-674. [CrossRef]

10. Papadaki, M.; Doukas, A.; Farinelli, W.A.; Kaban, L.; Troulis, M. Vertical ramus osteotomy with Er:YAG laser: A feasibility study. Int. J. Oral Maxillofac. Surg. 2007, 36, 1193-1197. [CrossRef]

11. González-García, A.; Diniz-Freitas, M.; Somoza-Martín, M.; García-García, A. Ultrasonic osteotomy in oral surgery and implantology. Oral Surg. Oral Med. Oral Pathol. Oral Radiol. Endod. 2009, 108, 360-367. [CrossRef] [PubMed]

12. Nelson, J.S.; Orenstein, A.; Liaw, L.L.; Berns, M.W. Mid-infrared erbium: YAG laser ablation of bone: The effect of laser osteotomy on bone healing. Lasers Surg. Med. 1989, 9, 362-374. [CrossRef] [PubMed]

13. O'Donnell, R.J.; Deutsch, T.F.; Flotte, T.J.; Lorente, C.A.; Tomford, W.W.; Mankin, H.J.; Schomacker, K.T. Effect of Er:YAG laser holes on osteoinduction in demineralized rat calvarial allografts. J. Orthop. Res. 1996, 14, 108-113. [CrossRef] [PubMed]

14. Giraud, J.Y.; Villemin, S.; Darmana, R.; Cahuzac, J.P.; Autefage, A.; Morucci, J.P. Bone cutting. Clin. Phys. Physiol. Meas. 1991, 12, 1-19. [CrossRef] [PubMed]

15. Singh, G.; Jain, V.; Gupta, D.; Sharma, A. Parametric effect of vibrational drilling on osteonecrosis and comparative histopathology study with conventional drilling of cortical bone. Proc. Inst. Mech. Eng. H 2018, 232, 975-986. [CrossRef]

16. Bertollo, N.; Milne, H.R.M.; Ellis, L.P.; Stephens, P.C.; Gillies, R.M.; Walsh, W.R. A comparison of the thermal properties of 2- and 3-fluted drills and the effects on bone cell viability and screw pull-out strength in an ovine model. Clin. Biomech. 2010, 25, 613-617. [CrossRef]

17. Anitua, E. Biological Bone Drilling in Oral Implantology. J. Dent. Oral Biol. 2017, 2, 2-3. 
18. Buza, J.A.; Einhorn, T. Bone healing in 2016. Clin. Cases Miner. Bone Metab. 2016, 13, 101-105. [CrossRef]

19. Jegoux, F.; Malard, O.; Goyenvalle, E.; Aguado, E.; Daculsi, G. Radiation effects on bone healing and reconstruction: Interpretation of the literature. Oral Surg. Oral Med. Oral Pathol. Oral Radiol. 2010, 109, 173-184. [CrossRef]

20. Evans, H.B.; Brown, S.; Hurst, L.N. The Effects of Early Postoperative Radiation on Vascularized Bone Grafts. Ann. Plast. Surg. 1991, 26, 505-510. [CrossRef]

21. Brasseur, M.; Brogniez, V.; Grégoire, V.; Reychler, H.; Lengelé, B.; D’Hoore, W.; Nyssen-Behets, C. Effects of irradiation on bone remodelling around mandibular implants: An experimental study in dogs. Int. J. Oral Maxillofac. Surg. 2006, 35, 850-855. [CrossRef] [PubMed]

22. Brogniez, V.; Nyssen-Behets, C.; Reychler, H.; Benoit, L. Implant osseointegration in the irradiated mandible microradiographic and histologic assessment. Clin. Oral Implant. Res. 1998, 234-242.

23. Schon, R.; Ohno, K.; Kudo, M.; Michi, K. Peri-implant tissue reaction in bone irradiated the fifth day after implantation in rabbits: Histologic and histomorphometric measurements. Int. J. Oral Maxillofac. Implant. 1996, 11, 228-238.

24. Marsell, R.; Einhorn, T.A. The biology of fracture healing. Injury 2012, 42, 551-555. [CrossRef] [PubMed]

25. Harris, J.P.; Chen, M.; Orosco, R.K.; Sirjani, D.; Divi, V.; Hara, W. Association of survival with shorter time to radiation therapy after surgery for US patients with head and neck cancer. JAMA Otolaryngol. Head Neck Surg. 2018, 144, 349-359. [CrossRef]

26. Davidson, S.R.H.; James, D.F. Drilling in bone: Modeling heat generation and temperature distribution. J. Biomech. Eng. 2003, 125, 305-314. [CrossRef]

27. Mediouni, M.; Kucklick, T.; Poncet, S.; Madiouni, R.; Abouaomar, A.; Madry, H.; Cucchiarini, M.; Chopko, B.; Vaughan, N.; Arora, M.; et al. An overview of thermal necrosis: Present and future. Curr. Med. Res. Opin. 2019, 35, 1555-1562. [CrossRef]

28. Dolan, E.B.; Haugh, M.G.; Tallon, D.; Casey, C.; McNamara, L.M. Heat-shock-induced cellular responses to temperature elevations occurring during orthopaedic cutting. J. R. Soc. Interface 2012, 9, 3503-3513. [CrossRef]

29. Yacker, M.J.; Klein, M. The Effect of Irrigation on Osteotomy Depth and Bur Diameter. Int. J. Oral Maxillofac. Implant. 1996, 11, 634-638.

30. Matthews, L.S.; Hirsch, C. Temperatures measured in human cortical bone when drilling. J. Bone Jt. Surg. Am. 1972, 54, 297-308. [CrossRef]

31. Kondo, S.; Okada, Y.; Iseki, H.; Hori, T.; Takakura, K.; Kobayashi, A.; Nagata, H. Thermological study of drilling bone tissue with a high-speed drill. Neurosurgery 2000, 46, 1162-1168. [CrossRef] [PubMed]

32. Pandey, R.K.; Panda, S.S. Drilling of bone: A comprehensive review. J. Clin. Orthop. Trauma 2013, 4, 15-30. [CrossRef] [PubMed]

33. Augustin, G.; Davila, S.; Mihoci, K.; Udiljak, T.; Vedrina, D.S.; Antabak, A. Thermal osteonecrosis and bone drilling parameters revisited. Arch. Orthop. Trauma Surg. 2008, 128, 71-77. [CrossRef] [PubMed]

34. Iwaniec, U.T.; Wronski, T.J.; Turner, R.T. Histological analysis of bone. Methods Mol. Biol. 2008, 447, 325-341. [PubMed]

35. Hancox, N.M.; Gejvall, N.G.; Hancox, N.M.; Gejvall, N.G. Biology of Bone, 1st ed.; Press, C.U., Ed.; Cambridge University Press: New York, NY, USA, 1972; Volume 10, ISBN 0521083427.

36. Bentolila, V.; Boyce, T.M.; Fyhrie, D.P.; Drumb, R.; Skerry, T.M.; Schaffler, M.B. Intracortical remodeling in adult rat long bones after fatigue loading. Bone 1998, 23, 275-281. [CrossRef]

37. Liao, Z.; Axinte, D.A.; Gao, D. A novel cutting tool design to avoid surface damage in bone machining. Int. J. Mach. Tools Manuf. 2017, 116, 52-59. [CrossRef]

38. Christen, P.; Ito, K.; Ellouz, R.; Boutroy, S.; Sornay-Rendu, E.; Chapurlat, R.D.; Van Rietbergen, B. Bone remodelling in humans is load-driven but not lazy. Nat. Commun. 2014, 5, 4855. [CrossRef]

39. Sugita, N.; Osa, T.; Mitsuishi, M. Analysis and estimation of cutting-temperature distribution during end milling in relation to orthopedic surgery. Med. Eng. Phys. 2009, 31, 101-107. [CrossRef]

40. Lee, J.E.; Gozen, B.A.; Ozdoganlar, O.B. Modeling and experimentation of bone drilling forces. J. Biomech. 2012, 45, 1076-1083. [CrossRef]

41. Bigham-Sadegh, A.; Oryan, A. Basic concepts regarding fracture healing and the current options and future directions in managing bone fractures. Int. Wound J. 2015, 12, 238-247. [CrossRef] 
42. Schindeler, A.; McDonald, M.M.; Bokko, P.; Little, D.G. Bone remodeling during fracture repair: The cellular picture. Semin. Cell Dev. Biol. 2008, 19, 459-466. [CrossRef] [PubMed]

43. Lieberman, J.R.; Daluiski, A.; Einhorn, T.A. The role of growth factors in the repair of bone biology and clinical applications. J. Bone Jt. Surg. Am. 2002, 1032-1044. [CrossRef] [PubMed]

44. Ferretti, M.; Palumbo, C.; Contri, M.; Marotti, G. Static and dynamic osteogenesis: Two different types of bone formation. Anat. Embryol. (Berl.) 2002, 206, 21-29. [CrossRef] [PubMed]

45. Palumbo, C.; Ferretti, M.; Marotti, G. Osteocyte dendrogenesis in static and dynamic bone formation: An ultrastructural study. Anat. Rec. 2004, 278A, 474-480. [CrossRef] [PubMed]

46. Marotti, G. Static and dynamic osteogenesis in the processes of bone repair. G Ital. di Ortop e Traumatol. 2004, 30, S1-S5.

47. Marotti, G.; Zaffe, D.; Ferretti, M.; Palumbo, C. Static osteogenesis and dynamic osteogenesis: Their relevance in dental bone implants and biomaterial osseointegration. J. Osteol. Biomater. 2010, 1, 133-139.

48. Streeten, E.A.; Brandi, M.L. Biology of bone endothelial cells. Bone Miner. 1990, 10, 85-94. [CrossRef]

49. Villanueva, J.E.; Nimni, M.E. Promotion of calvarial cell osteogenesis by endothelial cells. J. Bone Miner. Res. 2009, 5, 733-739. [CrossRef]

50. Kasperk, C.H.; Börcsök, I.; Schairer, H.U.; Schneider, U.; Nawroth, P.P.; Niethard, F.U.; Ziegler, R. Endothelin-1 is a potent regulator of human bone cell metabolism in vitro. Calcif. Tissue Int. 1997, 60, 368-374. [CrossRef]

51. Inoue, A.; Kamiya, A.; Ishiji, A.; Hiruma, Y.; Hirose, S.; Hagiwara, H. Vasoactive peptide-regulated gene expression during osteoblastic differentiation. J. Cardiovasc. Pharmacol. 2000, 36, S286-S289. [CrossRef] [PubMed]

52. Ferretti, M.; Palumbo, C.; Bertoni, L.; Cavani, F.; Marotti, G. Does static precede dynamic osteogenesis in endochondral ossification as occurs in intramembranous ossification? Anat. Rec. Part A Discov. Mol. Cell. Evol. Biol. 2006, 288A, 1158-1162. [CrossRef] [PubMed]

53. Remedios, A. Bone and Bone Healing. Vet. Clin. N. Am. Small Anim. Pract. 1999, 29, 1029-1044. [CrossRef]

54. Barré-Sinoussi, F.; Montagutelli, X. Animal models are essential to biological research: Issues and perspectives. Future Sci. OA 2015, 1. [CrossRef]

55. Peker Tekdal, G.; Bostanci, N.; Belibasakis, G.N.; Gürkan, A. The effect of piezoelectric surgery implant osteotomy on radiological and molecular parameters of peri-implant crestal bone loss: A randomized, controlled, split-mouth trial. Clin. Oral Implant. Res. 2016, 27, 535-544. [CrossRef] [PubMed]

56. Gülnahar, Y.; Hüseyin Köşger, H.; Tutar, Y. A comparison of piezosurgery and conventional surgery by heat shock protein 70 expression. Int. J. Oral Maxillofac. Surg. 2013, 42, 508-510. [CrossRef] [PubMed]

57. Aerssens, J.; Boonen, S.; Lowet, G.; Dequeker, J. Interspecies differences in bone composition, density, and quality: Potential implications for in vivo bone research. Endocrinology 1998, 139, 663-670. [CrossRef] [PubMed]

58. McGovern, J.A.; Griffin, M.; Hutmacher, D.W. Animal models for bone tissue engineering and modelling disease. Dis. Model. Mech. 2018, 11. [CrossRef] [PubMed]

59. Pearce, A.I.; Richards, R.G.; Milz, S.; Schneider, E.; Pearce, S.G. Animal models for implant biomaterial research in bone: A review. Eur. Cell. Mater. 2007, 13,1-10. [CrossRef]

60. Reeve-Johnson, L.; Schuetz, M. A Review of Major Animal Models Relevant to Contemporary Orthopaedic Repair of the Appendicular Skeleton in Humans. EC Orthop. 2016, 4, 537-552.

61. Reichert, J.C.; Saifzadeh, S.; Wullschleger, M.E.; Epari, D.R.; Schütz, M.A.; Duda, G.N.; Schell, H.; van Griensven, M.; Redl, H.; Hutmacher, D.W. The challenge of establishing preclinical models for segmental bone defect research. Biomaterials 2009, 30, 2149-2163. [CrossRef]

62. Schafrum Macedo, A.; Cezaretti Feitosa, C.; Yoiti Kitamura Kawamoto, F.; Vinicius Tertuliano Marinho, P.; dos Santos Dal-Bó, Í; Fiuza Monteiro, B.; Prado, L.; Bregadioli, T.; Antonio Covino Diamante, G.; Ricardo Auada Ferrigno, C. Animal modeling in bone research—Should we follow the White Rabbit? Anim. Model. Exp. Med. 2019, 2, 162-168. [CrossRef] [PubMed]

63. Wancket, L.M. Animal Models for Evaluation of Bone Implants and Devices. Vet. Pathol. 2015, 52, 842-850. [CrossRef] [PubMed]

64. Bellucci, D.; Cannillo, V.; Anesi, A.; Salvatori, R.; Chiarini, L.; Manfredini, T.; Zaffe, D. Bone Regeneration by Novel Bioactive Glasses Containing Strontium and/or Magnesium: A Preliminary In-Vivo Study. Materials 2018, 11, 2223. [CrossRef] [PubMed] 
65. Bellucci, D.; Anesi, A.; Salvatori, R.; Chiarini, L.; Cannillo, V. A comparative in vivo evaluation of bioactive glasses and bioactive glass-based composites for bone tissue repair. Mater. Sci. Eng. C 2017, 79, $286-295$. [CrossRef]

66. Russell, W.M.S.; Burch, R.L. The Principles of Human Experimental Technique; Methuen, UFAW: London, UK, 1959; Available online: http://117.239.25.194:7000/jspui/bitstream/123456789/1342/1/PRILIMINERY\%20\% 20AND\%20\%20CONTENTS.pdf (accessed on 10 April 2020).

67. European Commission. Annex to the Communication from the Commission on the European Citizen's Initiative, 'Stop Vivisection'. European Commission; European Commission: Brussels, Belgium, 2015; Available online: https://ec.europa.eu/environment/chemicals/lab_animals/pdf/vivisection/en.pdf (accessed on 10 April 2020).

68. Strbac, G.D.; Giannis, K.; Unger, E.; Mittlböck, M.; Watzek, G.; Zechner, W. A novel standardized bone model for thermal evaluation of bone osteotomies with various irrigation methods. Clin. Oral Implant. Res. 2014, 25, 622-631. [CrossRef]

69. Davidson, S.R.H.; James, D.F. Measurement of thermal conductivity of bovine cortical bone. Med. Eng. Phys. 2000, 22, 741-747. [CrossRef]

70. Repubblica Italiana. Italian Laws for Protection of Animals Used for Scientific Purposes-DECRETO LEGISLATIVO 4 marzo 2014, n. 26-Repubblica Italiana. Available online: http://extwprlegs1.fao.org/docs/ pdf/ita153404.pdf (accessed on 10 April 2020).

71. Wang, X.; Mabrey, J.D.; Agrawal, C.M. An interspecies comparison of bone fracture properties. Biomed. Mater. Eng. 1998, 8, 1-9.

72. Stoetzer, M.; Felgenträger, D.; Kampmann, A.; Schumann, P.; Rücker, M.; Gellrich, N.-C.; von See, C. Effects of a new piezoelectric device on periosteal microcirculation after subperiosteal preparation. Microvasc. Res. 2014, 94, 114-118. [CrossRef]

73. Bellucci, D.; Salvatori, R.; Giannatiempo, J.; Anesi, A.; Bortolini, S.; Cannillo, V. A New Bioactive Glass/Collagen Hybrid Composite for Applications in Dentistry. Materials 2019, 12, 2079. [CrossRef]

74. Anesi, A.; Generali, L.; Sandoni, L.; Pozzi, S.; Grande, A. From Osteoclast Differentiation to Osteonecrosis of the Jaw: Molecular and Clinical Insights. Int. J. Mol. Sci. 2019, 20, 4925. [CrossRef]

75. Malavasi, G.; Salvatori, R.; Zambon, A.; Lusvardi, G.; Rigamonti, L.; Chiarini, L.; Anesi, A. Cytocompatibility of Potential Bioactive Cerium-Doped Glasses based on 45S5. Materials 2019, 12, 594. [CrossRef] [PubMed]

76. Li, Y.; Chen, S.K.; Li, L.; Qin, L.; Wang, X.L.; Lai, Y.-X. Bone defect animal models for testing efficacy of bone substitute biomaterials. J. Orthop. Transl. 2015, 3, 95-104. [CrossRef] [PubMed]

77. Palumbo, C.; Ferretti, M.; Ardizzoni, A.; Zaffe, D.; Marotti, G. Osteocyte-osteoclast morphological relationships and the putative role of osteocytes in bone remodeling. J. Musculoskelet. Neuronal Interact. 2001, 1, 327-332.

78. Moss, R.W. Histopathologic reaction of bone to surgical cutting. Oral Surg. Oral Med. Oral Pathol. 1964, 17, 405-414. [CrossRef]

79. Spatz, S. Early reaction in bone following the use of burs rotating at conventional and ultra speeds; A comparison study. Oral Surg. Oral Med. Oral Pathol. 1965, 19, 808-816. [CrossRef]

80. Horton, J.E.; Tarpley, T.M.; Wood, L.D. The healing of surgical defects in alveolar bone produced with ultrasonic instrumentation, chisel, and rotary bur. Oral Surg. Oral Med. Oral Pathol. 1975, 39, 536-546. [CrossRef]

81. Eriksson, A.R.; Albrektsson, T.; Albrektsson, B. Heat caused by drilling cortical bone: Temperature measured in vivo in patients and animals. Acta Orthop. Scand. 1984, 55, 629-631. [CrossRef] [PubMed]

82. Wächter, R.; Stoll, P. Increase of temperature during osteotomy. In vitro and in vivo investigations. Int. J. Oral Maxillofac. Surg. 1991, 20, 245-249. [CrossRef]

83. Abouzgia, M.B.; Symington, J.M. Effect of drill speed on bone temperature. Int. J. Oral Maxillofac. Surg. 1996, 25, 394-399. [CrossRef]

84. Keijser, L.C.; Schreuder, H.W.; Buma, P.; Weinans, H.; Veth, R.P. Cryosurgery in long bones; an experimental study of necrosis and revitalization in rabbits. Arch. Orthop. Trauma Surg. 1999, 119, 440-444. [CrossRef]

85. Bachus, K.N.; Rondina, M.T.; Hutchinson, D.T. The effects of drilling force on cortical temperatures and their duration: An in vitro study. Med. Eng. Phys. 2000, 22, 685-691. [CrossRef]

86. Vercellotti, T.; Nevins, M.L.; Kim, D.M.; Nevins, M.; Wada, K.; Schenk, R.K.; Fiorellini, J.P. Osseous response following resective therapy with piezosurgery. Int. J. Periodontics Restor. Dent. 2005, 25, 543-549. 
87. Preti, G.; Martinasso, G.; Peirone, B.; Navone, R.; Manzella, C.; Muzio, G.; Russo, C.; Canuto, R.A.; Schierano, G. Cytokines and growth factors involved in the osseointegration of oral titanium implants positioned using piezoelectric bone surgery versus a drill technique: A pilot study in minipigs. J. Periodontol. 2007, 78, 716-722. [CrossRef] [PubMed]

88. Maurer, P.; Kriwalsky, M.S.; Block Veras, R.; Vogel, J.; Syrowatka, F.; Heiss, C. Micromorphometrical analysis of conventional osteotomy techniques and ultrasonic osteotomy at the rabbit skull. Clin. Oral Implant. Res. 2008, 19, 570-575. [CrossRef]

89. Queiroz, T.P.; Souza, F.A.; Okamoto, R.; Margonar, R.; Pereira-Filho, V.A.; Garcia Júnior, I.R.; Vieira, E.H. Evaluation of immediate bone-cell viability and of drill wear after implant osteotomies: Immunohistochemistry and scanning electron microscopy analysis. J. Oral Maxillofac. Surg. 2008, 66, 1233-1240. [CrossRef]

90. Rashad, A.; Kaiser, A.; Prochnow, N.; Schmitz, I.; Hoffmann, E.; Maurer, P. Heat production during different ultrasonic and conventional osteotomy preparations for dental implants. Clin. Oral Implant. Res. 2011, 22, 1361-1365. [CrossRef]

91. Augustin, G.; Davila, S.; Udilljak, T.; Staroveski, T.; Brezak, D.; Babic, S. Temperature changes during cortical bone drilling with a newly designed step drill and an internally cooled drill. Int. Orthop. 2012, 36, 1449-1456. [CrossRef]

92. Heinemann, F.; Hasan, I.; Kunert-Keil, C.; Götz, W.; Gedrange, T.; Spassov, A.; Schweppe, J.; Gredes, T. Experimental and histological investigations of the bone using two different oscillating osteotomy techniques compared with conventional rotary osteotomy. Ann. Anat. 2012, 194, 165-170. [CrossRef]

93. Hollstein, S.; Hoffmann, E.; Vogel, J.; Heyroth, F.; Prochnow, N.; Maurer, P. Micromorphometrical analyses of five different ultrasonic osteotomy devices at the rabbit skull. Clin. Oral Implant. Res. 2012, 23, 713-718. [CrossRef]

94. Schütz, S.; Egger, J.; Kühl, S.; Filippi, A.; Lambrecht, J.T. Intraosseous temperature changes during the use of piezosurgical inserts in vitro. Int. J. Oral Maxillofac. Surg. 2012, 41, 1338-1343. [CrossRef]

95. Claire, S.; Lea, S.C.; Walmsley, A.D. Characterisation of bone following ultrasonic cutting. Clin. Oral Investig. 2013, 17, 905-912. [CrossRef] [PubMed]

96. Esteves, J.C.; Marcantonio, E.; de Souza Faloni, A.P.; Rocha, F.R.G.; Marcantonio, R.A.; Wilk, K.; Intini, G. Dynamics of bone healing after osteotomy with piezosurgery or conventional drilling-histomorphometrical, immunohistochemical, and molecular analysis. J. Transl. Med. 2013, 11, 221. [CrossRef] [PubMed]

97. Ma, L.; Stübinger, S.; Liu, X.L.; Schneider, U.A.; Lang, N.P. Healing of osteotomy sites applying either piezosurgery or two conventional saw blades: A pilot study in rabbits. Int. Orthop. 2013, 37, 1597-1603. [CrossRef] [PubMed]

98. Bullon, B.; Bueno, E.F.; Herrero, M.; Fernandez-Palacin, A.; Rios, J.V.; Bullon, P.; Gil, F.J. Effect of irrigation and stainless steel drills on dental implant bed heat generation. J. Mater. Sci. Mater. Med. 2015, $26,75$. [CrossRef] [PubMed]

99. Lamazza, L.; Laurito, D.; Lollobrigida, M.; Brugnoletti, O.; Garreffa, G.; De Biase, A. Identification of possible factors influencing temperatures elevation during implant site preparation with piezoelectric technique. Ann. Stomatol. (Roma) 2014, 5, 115-122. [PubMed]

100. Stelzle, F.; Frenkel, C.; Riemann, M.; Knipfer, C.; Stockmann, P.; Nkenke, E. The effect of load on heat production, thermal effects and expenditure of time during implant site preparation-An experimental ex vivo comparison between piezosurgery and conventional drilling. Clin. Oral Implant. Res. 2014, 25, e140-e148. [CrossRef] [PubMed]

101. Yang, B.E.; Girod, S. Efficacy of bone healing in calvarial defects using piezoelectric surgical instruments. J. Craniofac. Surg. 2014, 25, 149-153. [CrossRef]

102. Rashad, A.; Sadr-Eshkevari, P.; Heiland, M.; Smeets, R.; Hanken, H.; Gröbe, A.; Assaf, A.T.; Köhnke, R.H.; Mehryar, P.; Riecke, B.; et al. Intraosseous heat generation during sonic, ultrasonic and conventional osteotomy. J. Craniomaxillofac. Surg. 2015, 43, 1072-1077. [CrossRef] [PubMed]

103. Boa, K.; Barrak, I.; Varga, E.; Joob-Fancsaly, A.; Varga, E.; Piffko, J. Intraosseous generation of heat during guided surgical drilling: An ex vivo study of the effect of the temperature of the irrigating fluid. Br. J. Oral Maxillofac. Surg. 2016, 54, 904-908. [CrossRef] 
104. Gabrić, D.; Blašković, M.; Gjorgijevska, E.; Mladenov, M.; Tašič, B.; Jurič, I.B.; Ban, T. Evaluation of Bone Healing After Osteotomies Prepared With Er:YAG Laser in Contact and Noncontact Modes and Piezosurgery-An Animal Study. J. Oral Maxillofac. Surg. 2016, 74, 18-28. [CrossRef] [PubMed]

105. Lamazza, L.; Garreffa, G.; Laurito, D.; Lollobrigida, M.; Palmieri, L.; De Biase, A. Temperature Values Variability in Piezoelectric Implant Site Preparation: Differences between Cortical and Corticocancellous Bovine Bone. BioMed Res. Int. 2016, 2016, 6473680. [CrossRef] [PubMed]

106. Sagheb, K.; Kumar, V.V.; Azaripour, A.; Walter, C.; Al-Nawas, B.; Kämmerer, P.W. Comparison of conventional twist drill protocol and piezosurgery for implant insertion: An ex vivo study on different bone types. Clin. Oral Implant. Res. 2016, 28, 207-213. [CrossRef] [PubMed]

107. Szalma, J.; Vajta, L.; Lempel, E.; Tóth, Á.; Jeges, S.; Olasz, L. Intracanal temperature changes during bone preparations close to and penetrating the inferior alveolar canal: Drills versus piezosurgery. J. Craniomaxillofac. Surg. 2017, 45, 1622-1631. [CrossRef] [PubMed]

108. Favero, V.; Sakuma, S.; Apaza Alccayhuaman, K.A.; Benedetto, G.A.; Bengazi, F.; Botticelli, D. Healing at sites prepared using different drilling protocols. An experimental study in the tibiae of sheep. PLoS ONE 2018, 13, e0202957. [CrossRef] [PubMed]

109. Fugito Junior, K.; Cortes, A.R.; de Carvalho Destro, R.; Yoshimoto, M. Comparative Study on the Cutting Effectiveness and Heat Generation of Rotary Instruments Versus Piezoelectric Surgery Tips Using Scanning Electron Microscopy and Thermal Analysis. Int. J. Oral Maxillofac. Implant. 2018, 33, 345-350. [CrossRef]

110. Lajolo, C.; Valente, N.A.; Romandini, W.G.; Petruzzi, M.; Verdugo, F.; D'Addona, A. Bone heat generated using conventional implant drills versus piezosurgery unit during apical cortical plate perforation. J. Periodontol. 2018, 89, 661-668. [CrossRef]

111. Stacchi, C.; Robiony, M.; Jones, J.M.; Lombardi, T.; Verardi, S.; Lajolo, C.; Valente, N.A.; Romandini, W.G.; Petruzzi, M.; Verdugo, F.; et al. Letter to the editor: Re: Bone heat generated using conventional implant drills versus piezosurgery unit during apical cortical plate perforation. J. Periodontol. 2018, 89, 1161-1162. [CrossRef]

112. Stocchero, M.; Toia, M.; Jinno, Y.; Cecchinato, F.; Becktor, J.P.; Naito, Y.; Halldin, A.; Jimbo, R. Influence of different drilling preparation on cortical bone: A biomechanical, histological, and micro-CT study on sheep. Clin. Oral Implant. Res. 2018, 29, 707-715. [CrossRef]

113. Tepedino, M.; Romano, F.; Indolfi, M.; Aimetti, M. Heat Production and Drill Wear Following Osseous Resective Surgery: A Preliminary In Vitro SEM Study Comparing Piezosurgery and Conventional Drilling. Int. J. Periodontics Restor. Dent. 2018, 38, e33-e40. [CrossRef]

114. Zheng, Q.; Xia, L.; Zhang, X.; Zhang, C.; Hu, Y. Reduction thermal damage to cortical bone using ultrasonically-assisted drilling. Technol. Health Care 2018, 26, 843-856. [CrossRef]

115. Alam, K.; Al-Ghaithi, A.; Piya, S.; Saleem, A. In-vitro experimental study of histopathology of bone in vibrational drilling. Med. Eng. Phys. 2019, 67, 78-87. [CrossRef] [PubMed]

116. Pavone, C.; Scardueli, C.R.; de Oliveira, G.J.P.L.; Cerri, P.S.; Marcantonio Junior, E.; Marcantonio, R.A.C. Effects of an Er,Cr:YSGG Laser on Bone Regeneration in Critical-Sized Calvarial Defects of Rats Exposed to Inhalation of Cigarette Smoke. Photobiomodul. Photomed. Laser Surg. 2019, 37, 500-507. [CrossRef] [PubMed]

117. Zhang, Y.; Xu, L.; Wang, C.; Chen, Z.; Han, S.; Chen, B.; Chen, J. Mechanical and thermal damage in cortical bone drilling in vivo. Proc. Inst. Mech. Eng. H 2019, 233, 621-635. [CrossRef] [PubMed]

118. Crovace, A.M.; Luzzi, S.; Lacitignola, L.; Fatone, G.; Lucifero, A.G.; Vercellotti, T.; Crovace, A. Minimal invasive piezoelectric osteotomy in neurosurgery: Technic, applications, and clinical outcomes of a retrospective case series. Vet. Sci. 2020, 7, 68. [CrossRef] [PubMed]

119. Thompson, H.C. Effect of Drilling lnto Bone. J. Oral Surg. 1958, 16, 22-30.

120. Eriksson, A.R.; Albrektsson, T. Temperature threshold levels for heat-induced bone tissue injury: A vital-microscopic study in the rabbit. J. Prosthet. Dent. 1983, 50, 101-107. [CrossRef]

121. Schwieger, K.; Carrero, V.; Rentzsch, R.; Becker, A.; Bishop, N.; Hille, E.; Louis, H.; Morlock, M.; Honl, M. Abrasive water jet cutting as a new procedure for cutting cancellous bone?In vitro testing in comparison with the oscillating saw. J. Biomed. Mater. Res. 2004, 71B, 223-228. [CrossRef]

122. Sharawy, M.; Misch, C.E.; Weller, N.; Tehemar, S. Heat generation during implant drilling: The significance of motor speed. J. Oral Maxillofac. Surg. 2002, 60, 1160-1169. [CrossRef]

123. Ark, T.W.; Neal, J.G.; Thacker, J.G.; Edlich, R.F. Influence of irrigation solutions on oscillating bone saw blade performance. J. Biomed. Mater. Res. 1998, 43, 108-112. [CrossRef] 
124. Happe, A. Use of a piezoelectric surgical device to harvest bone grafts from the mandibular ramus: Report of 40 cases. Int. J. Periodontics Restor. Dent. 2007, 3, 241-249.

125. Sohn, D.-S.; Ahn, M.-R.; Lee, W.H.; Yeo, D.S.; Lim, S.-Y. Piezoelectric osteotomy for intraoral harvesting of bone blocks. Int. J. Periodontics Restor. Dent. 2007, 2, 127-131.

126. Valente, N.; Cosma, L.; Nocca, G.; D’Addona, A.; Lajolo, C. Piezoelectric Device Versus Conventional Osteotomy Instruments in the Comparison of Three Different Bone Harvesting Methods: An Istomorphometric, Phonometric, and Chronometric Evaluation. Int. J. Oral Maxillofac. Implant. 2019, 34, 1070-1077. [CrossRef] [PubMed]

127. Mehmanparast, H.; Petit, Y.; Mac-Thiong, J.-M. Comparison of Pedicle Screw Loosening Mechanisms and the Effect on Fixation Strength. J. Biomech. Eng. 2015, 137, 121003. [CrossRef] [PubMed]

128. Zhang, X.; Liu, X.; Yan, Z.; Cai, J.; Kang, F.; Shan, S.; Wang, P.; Zhai, M.; Edward Guo, X.; Luo, E.; et al. Spatiotemporal characterization of microdamage accumulation in rat ulnae in response to uniaxial compressive fatigue loading. Bone 2018, 108, 156-164. [CrossRef]

Publisher's Note: MDPI stays neutral with regard to jurisdictional claims in published maps and institutional affiliations.

(C) 2020 by the authors. Licensee MDPI, Basel, Switzerland. This article is an open access article distributed under the terms and conditions of the Creative Commons Attribution (CC BY) license (http://creativecommons.org/licenses/by/4.0/). 